\title{
Soil Organic Carbon Distribution in a Humid Tropical Plain of Cameroon: Interrelationships with Soil Properties
}

\author{
Georges Kogge Kome (D), Roger Kogge Enang, and Bernard Palmer Kfuban Yerima \\ Department of Soil Science, Faculty of Agronomy and Agricultural Sciences (FASA), University of Dschang, P.O. Box 222, \\ Dschang, Cameroon \\ Correspondence should be addressed to Georges Kogge Kome; komegeo@yahoo.fr
}

Received 25 March 2020; Revised 16 January 2021; Accepted 3 February 2021; Published 27 February 2021

Academic Editor: Maman Turjaman

Copyright ( 2021 Georges Kogge Kome et al. This is an open access article distributed under the Creative Commons Attribution License, which permits unrestricted use, distribution, and reproduction in any medium, provided the original work is properly cited.

\begin{abstract}
Soil organic carbon (SOC) determination is very important in the assessment of agronomic potential of a soil. The objective of this study was to determine SOC contents and stock distribution with depth in relation to selected soil properties. Five types of soils, namely, Mollic Endoaquents, Oxyaquic Paleudalfs, Oxyaquic Udifluvents, and Mollic Udifluvents from a humid tropical plain and Typic Eutrudepts from an adjacent foot slope, were studied. The soils have all developed from fluvial sediments. Morphological and physicochemical characteristics of the soils were obtained using standard methods. Soil texture varied across the different sites and within soil profiles with textural classes of genetic horizons ranging from sandy loam to heavy clay. The soils are generally young soils under development as indicated by their high silt/clay ratios which ranged between 0.23 and 2.45 . All the soils were generally acidic with $\mathrm{pH}-\mathrm{H}_{2} \mathrm{O}$ values ranging from 4.5 to 6.2 . Exchangeable $\mathrm{H}^{+}$and $\mathrm{Al}^{3+}$ ranged from 0.5 to 2.3 and 0.2 to 3.3 $\mathrm{cmol}_{\mathrm{c}} \mathrm{kg}^{-1}$, respectively. SOC contents are generally higher in surface horizons and decrease with depth. In general, SOC correlated significantly with bulk density (BD) $(r=-0.648, p<0.01)$, water holding capacity $(r=0.589, p<0.01)$, exchangeable $\mathrm{Al}^{3+}(r=0.707, p<0.01)$, and exchangeable $\mathrm{H}^{+}(r=0.456, p<0.05)$. The correlation between SOC and exchangeable $\mathrm{Al}^{3+}$ was strongest in the Mollic Endoaquents $(r=0.931, p<0.01)$. SOC contents correlated significantly with Munsell soil color attributes, explaining between 40 and $57 \%$ of SOC variation. Total SOC stocks at a depth of $100 \mathrm{~cm}$ varied between 260.1 and $363.5 \mathrm{t} \cdot \mathrm{ha} \mathrm{a}^{-1}$, and the variation in SOC stocks across a profile appears to be controlled by genetic horizon depth, while land use type influences SOC stock variations across genetic surface horizons.
\end{abstract}

\section{Introduction}

Soil organic carbon (SOC) is a major indicator of soil quality and productivity and also a key driver of most soil processes and functions. It influences nutrient retention, microaggregate formation and soil structure, water retention/ storage and infiltration, microbial activity, and $\mathrm{pH}$ buffering [1]. SOC is also fundamental to the role played by soil in providing ecosystem services such as regulating services (e.g., carbon sequestration, climate and greenhouse gas regulations), provisioning services (e.g., food, water, fuel, fiber), cultural services (e.g., ecotourism and recreation), and supporting services such as nutrient cycling [2]. Soils play a very important role in climate change adaptation and mitigation by regulating the global carbon cycle and have been identified as the largest pool of terrestrial organic carbon in the biosphere, with a carbon storage capacity surpassing that contained in plants and the atmosphere combined. According to Batjes [3], the top meter of the world's soils stores about $2200 \mathrm{Pg}$ of C, with about twothirds $(66 \%)$ of it stored as soil organic matter. This amount of $\mathrm{C}$ is almost thrice that found in the atmosphere. Under natural conditions, the storage of $\mathrm{OC}$ in soil is controlled by the balance of $\mathrm{C}$ inputs from plant production and outputs through decomposition [4]. However, anthropogenic disturbances, mainly agricultural activities and forest clearance for fuel and timber, greatly contribute to the emission of large quantities of the stored carbon into the atmosphere [5]. On the other hand, improved cultivation practices such as addition of biochar [6], incorporation of crop residues [7, 8], 
and conservation tillage [9-11] can significantly increase soil carbon sequestration. Apart from the influence of human activities, many biophysical factors influence SOC storage and distribution patterns (Table 1).

In general, SOC exists in three distinct fractions, namely, passive, intermediate, and active [35]. The active and intermediate fractions are found in the top 1 meter of soil and are often collectively known as labile SOC [36]. The SOC found in this fraction is biologically available and more susceptible to changes at the soil surface [37]. The labile fraction is the smallest pool of SOC and is estimated at 250-350 Pg [36]. This fraction originates from fresh organic residues and living organisms, and its turnover ranges from days to few decades. On the other hand, the passive or more stable fraction of SOC (chemically stable in the form of humus) is often found concentrated below $1 \mathrm{~m}$ and is not readily accessible to microorganisms for decomposition [36].

This stable fraction includes fine-sized organic matter that is physically protected (e.g., clay mineral-protected or contained within soil aggregates) or chemically persistent (humus) in soil. The turnover period of this fraction ranges from centuries to millennia [35]. The subsoil contains the largest pool of SOC and is the least likely to be influenced by changes in management practice and different environmental conditions than top soil [50].

Monitoring and quantifying SOC contents and stocks across landscape units and over time are crucial for the assessment of spatial and temporal variations in SOC pools and fluxes. More specifically, SOC stock estimates are important for global climate change predictions [51]. This is also very useful in understanding changes in soil fertility/ productivity levels, soil deterioration/amelioration, water quality, environmental degradation, etc., hence necessitating the adoption of sustainable soil management practices for enhancing SOC storage and increased ecosystem services. However, data availability for assessing environmental changes is a major constraint, especially in most developing countries of tropical environments. This is mainly associated with a lack of adequate research facilities and too much generalization about tropical soils [52], confirming the assertion that much is still unknown about the soil resources in tropical environments compared to those in temperate regions [53]. Inventories of SOC stocks at local scales are useful and can readily be used to assist most countries in achieving the goals of the United Nations Framework Convention on Climate Change (UNFCCC).

The nonexistence of a national SOC database for Cameroon [54] could limit its ability to access funds from the Clean Development Mechanism (CDM) as proposed under article 12 of the Kyoto Protocol of the UNFCCC. The CDM allows developing countries to establish emission reduction (or emission removal) projects that can earn certified emission reductions (CERs), each equivalent to $1 \mathrm{t}$ of $\mathrm{CO}_{2}$, that can then be traded and sold, and used by industrialized countries to meet some of their emission reduction targets under the Kyoto Protocol. Thus, estimation of SOC stocks at local scales constitutes baselines for large-scale inventories that would significantly improve the accuracy of national SOC databases. In Cameroon, a dearth of information exists on the $\mathrm{C}$ sequestration potential of plain soils. Like in most areas worldwide, plains in Cameroon constitute areas of intensive agricultural production that would significantly impact on the soil carbon storage potential. The objective of this study was to determine SOC contents and their distribution with depth in relation to selected soil physicochemical and morphological properties in five dominant soil types within the Mbo plain.

\section{Materials and Methods}

2.1. Location and Characteristics of the Study Area. The Mbo

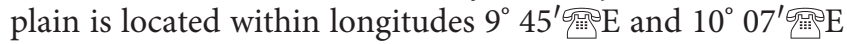
and latitudes $5^{\circ} 07^{\prime}$ 留 $\mathrm{N}$ and $5^{\circ} 25^{\prime}$ 留 $\mathrm{N}$. The plain has an average altitude of $720 \mathrm{~m}$ above sea level and extends over a surface area of about 30,000 ha. It lies between the Bamiléké plateau (1400-2000 m) in the north and east, the dorsal part of the Ekomane Mountain (about $1800 \mathrm{~m}$ ) in the west, and the Manengouba volcanic massif $(2400 \mathrm{~m})$ in the south (Figure 1). Geomorphologically, the Mbo plain is an ancient lake depression on a granite-gneissic base, resulting from deposits of the first volcanic eruptions of Mount Manengouba [55]. A lava flow of this eruption blocked the plain in the north, favoring the creation of a lake. This was followed by the draining of this lake by the Nkam River, causing its disappearance [55]. The northern and eastern parts of the Mbo plain are dominated by the Bamiléké plateau comprised of granite and gneiss, with very steep escarpments. The southern part of the plain is dominated by basalt lava flow from Mount Manengouba which descends progressively towards the plain [56]. Between these borders is a vast depression occupied by swamps containing a dense hydrographic network of many streams and the Nkam River.

The vegetation distribution in the Mbo plain is conditioned by hydrologic and edaphic factors [57]. The remaining semideciduous forests are mostly found at the peripheries of the plain, on the flanks of the mountains which dominate it. It is on glacis that most of the forest in the Mbo plain has been destroyed for the establishment of farmlands and plantations. On relatively nutrient-poor zones, Hyparrhenia sp. and some teak (Tectona grandis) plantations abound. On well-drained areas gallery forests haveing considerably reduced in size following clearing for the establishment of farmlands and settlement. Vast areas within the $M b o$ plain are either permanently or seasonally flooded, especially in depressions. These depressions are covered by fern (Pteridium aquilinum), raffia (Raphia farinifera), oil palm (Elaeis guineensis), and screw pine (Pandanus sp.). The dominant farming system in the Mbo plain consists of intensive cultivation of both annual and perennial crops for both subsistence and commercial purposes. The dominant crops cultivated include cassava (Manihot 
TABLE 1: Major biophysical factors influencing SOC storage and distribution patterns.

\begin{tabular}{lc}
\hline Biophysical factors & References \\
\hline Vegetation type & {$[12] ;[13] ;[14]$} \\
Soil biodiversity & {$[15]$} \\
Soil texture & {$[13] ;[16] ;[17] ;[18]$} \\
Soil pH & {$[19] ;[20] ;[21]$} \\
Soil microaggregates & {$[22] ;[23] ;[24]$} \\
Temperature (sensitivity of SOC decomposition) & {$[25]$} \\
Climate & {$[12] ;[17] ;[26] ;[27] ;[28]$} \\
Precipitation & {$[29]$} \\
Leaching of carbonates & {$[30] ;[31]$} \\
Mineralogy & {$[21] ;[32] ;[33] ;[34]$} \\
Soil erosion & {$[1] ;[38] ;[39] ;[40]$} \\
Topography & {$[12] ;[40] ;[41] ;[42]$} \\
Soil depth & {$[3] ;[26] ;[43] ;[44]$} \\
Soil type (reference group) & {$[12] ;[27]$} \\
Vegetation fires & {$[45] ;[46] ;[47]$} \\
Accelerated SOM decomposition caused by global warming & {$[31] ;[48] ;[49]$} \\
\hline
\end{tabular}

esculenta), cocoyam (Colocasia esculenta), sweet potatoes (Ipomoea batatas), maize (Zea mays), plantain and banana (Musa spp.), cocoa (Theobroma cacao), coffee (Coffea arabica), ginger (Zingiber officinale), and a wide variety of vegetables and fruits. Vast untapped arable lands in the Santchou and Mbomi areas of this plain have high potential for developing large-scale rice production.

Following the Köppen-Geiger classification, the climate in the Mbo plain is described as Am (tropical monsoon climate), occasionally known as a tropical wet climate or tropical monsoon or trade-wind littoral climate. Mean monthly temperatures are generally above $18^{\circ} \mathrm{C}$ in every month of the year, with two distinct seasons prevailing-the rainy (wet) season which runs from March to October and the dry season which runs from November to February (Figure 2). The difference in rainfall between the driest and wettest month is about $420 \mathrm{~mm}$. Mean annual temperature is about $23.6^{\circ} \mathrm{C}$ with an annual temperature variation of $2.7^{\circ} \mathrm{C}$, and mean annual rainfall is about $2500 \mathrm{~mm}$. The hottest month is March, with a mean monthly temperature of $24.8^{\circ} \mathrm{C}$, while the coldest month is August with a mean monthly temperature of $22.1^{\circ} \mathrm{C}$. Average relative humidity is high throughout the year $(>70 \%)$ and highest in the months of July and August (>90\%). Winds are relatively high during the months of December and January.

2.2. Field Methods and Laboratory Analyses. A survey was conducted on five soil profiles representing the major land use/cover types and geomorphological features (Table 2, Figure 3). Major environmental characteristics, physiography, and soil profiles were described in the field following standard procedures [60]. Bulk soil samples from each genetic horizon were collected and stored in polythene bags. In addition, undisturbed core samples for bulk density determination were collected from each genetic horizon using stainless steel Kopecky rings.

Soil samples from the field were air-dried and crushed using a porcelain mortar and pestle and then sieved through a $2 \mathrm{~mm}$ sieve to remove coarse fragments, roots, and plant residues. The $<2 \mathrm{~mm}$ soil fraction was used for the various physicochemical analyses. Soil $\mathrm{pH}$ was measured in distilled deionized water, $1 \mathrm{M} \mathrm{KCl}$, and $0.01 \mathrm{M}$ $\mathrm{CaCl}_{2}$ in a $1: 2.5$ soil-to-solution ratio as described by Kome et al. [61]. Soil electrical conductivity was determined in a 1:5 soil-to-solution ratio using distilled deionized water and a conductivity meter as described by Kome et al. [61]. Soil organic carbon was determined using the Walkley-Black method [62]. Bulk density was calculated as the oven dry $\left(105^{\circ} \mathrm{C}\right)$ mass of undisturbed core sample per volume. Particle size analysis was conducted using the hydrometer method as described by Bouyoucos [63]. Effective dispersal of the soil samples was achieved using a $2.5 \mathrm{~N}$ solution of sodium hexametaphosphate. The relative proportions of sand, silt, and clay were used to calculate the sand/silt and silt/clay ratios, while the clay ratio was calculated using the formula

$$
\text { clay ratio }=\frac{\% \text { clay }}{(\% \text { sand }+\% \text { silt })} \text {. }
$$

Water holding capacity (WHC) was determined following procedures described by Pansu and Gautheyrou [64].

2.3. Estimation of SOC Stocks. Soil organic carbon stocks per horizon were estimated using the genetic horizon equation [65] as follows:

$$
\begin{aligned}
\operatorname{SOC} \text { stock }\left(\mathrm{tha}^{-1}\right)= & \left(\frac{\mathrm{mg} \text { SOC }}{\mathrm{g} \text { soil }}\right) \times\left(\frac{\mathrm{g} \text { soil }}{\mathrm{cm}^{3} \text { soil }}\right) \\
& \times\left(\frac{\mathrm{cm}}{1}\right) \times\left(\frac{t}{10^{9} \mathrm{mg}}\right) \times\left(\frac{10^{8} \mathrm{~cm}^{2}}{\mathrm{ha}}\right) \\
& \times\left(1-\delta_{2 \mathrm{~mm}} \%\right) .
\end{aligned}
$$

Total SOC stock per soil profile to a depth of $1 \mathrm{~m}$ was estimated by summing the SOC stocks per genetic horizon: 


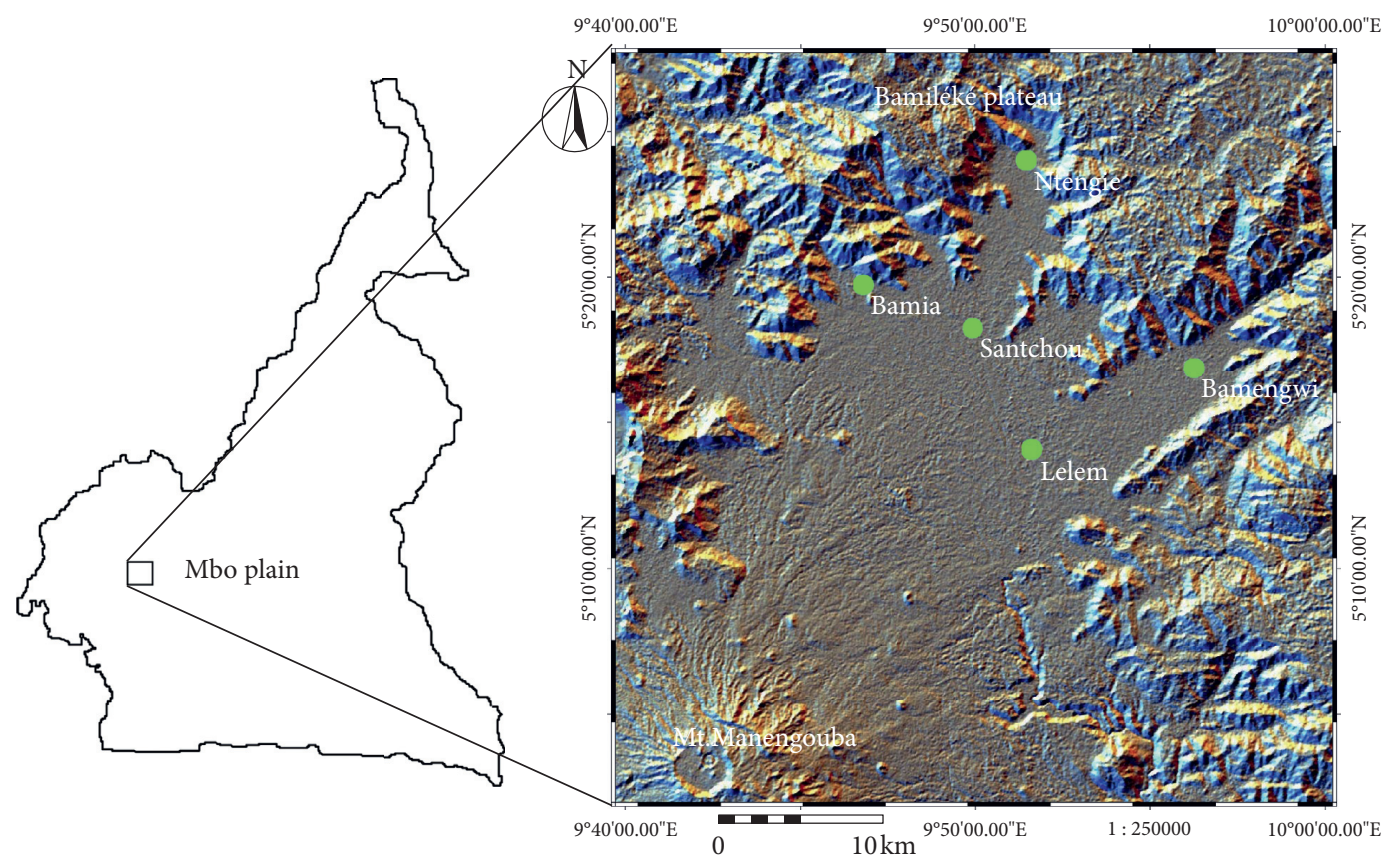

(a)

(b)

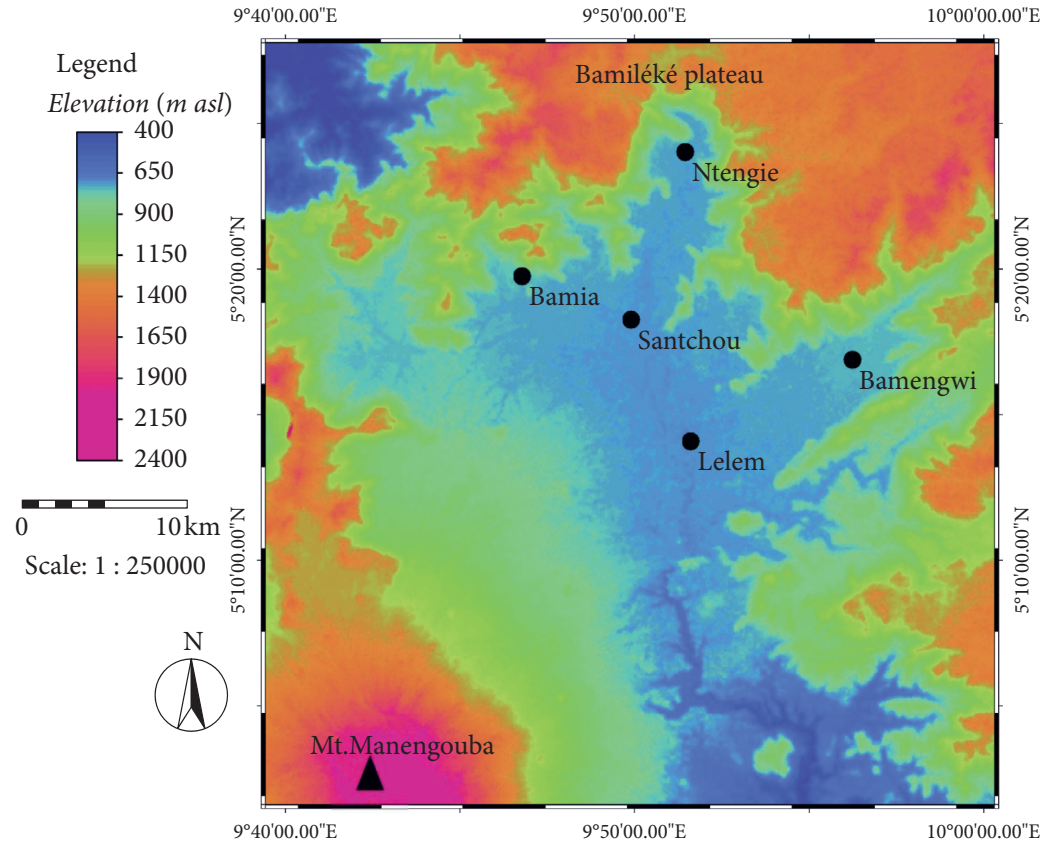

(c)

Figure 1: Location of the Mbo plain in Cameroon. (a) DEM (b) and topographic (c) maps of the Mbo plain showing location of the study sites.

$$
\begin{aligned}
\text { total SOC stock }\left(\mathrm{tha}^{-1}\right)= & \sum_{i}^{n}\left(\frac{\mathrm{mg} \text { SOC }}{\mathrm{g} \text { soil }}\right) \times\left(\frac{\mathrm{g} \text { soil }}{\mathrm{cm}^{3} \text { soil }}\right) \\
& \times\left(\frac{\mathrm{cm}}{1}\right) \times\left(\frac{\mathrm{t}}{10^{9} \mathrm{mg}}\right) \\
& \times\left(\frac{10^{8} \mathrm{~cm}^{2}}{\mathrm{ha}}\right) \times\left(1-\delta_{2 \mathrm{~mm} \%)}\right)
\end{aligned}
$$

where mg SOC $\mathrm{g} \mathrm{soil}^{-1}$ is SOC concentration, $\mathrm{g}$ soil $\mathrm{cm} \mathrm{soil}^{-3}$ is bulk density, $\mathrm{cm}$ is soil horizon thickness, and $\delta_{2 \mathrm{~mm}} \%$ is fractional percentage (\%) of $>2 \mathrm{~mm}$ coarse fragments by volume.

Genetic soil horizons of entire soil profiles were used to estimate SOC stocks rather than soil control sections because the latter has been proven to overestimate SOC stocks [44].

2.4. Statistical Analyses. The relationships between soil properties were established using correlation and regression analyses. Statistical analyses were performed using Microsoft Excel 2007 and SPSS (Version 23) for Windows. 


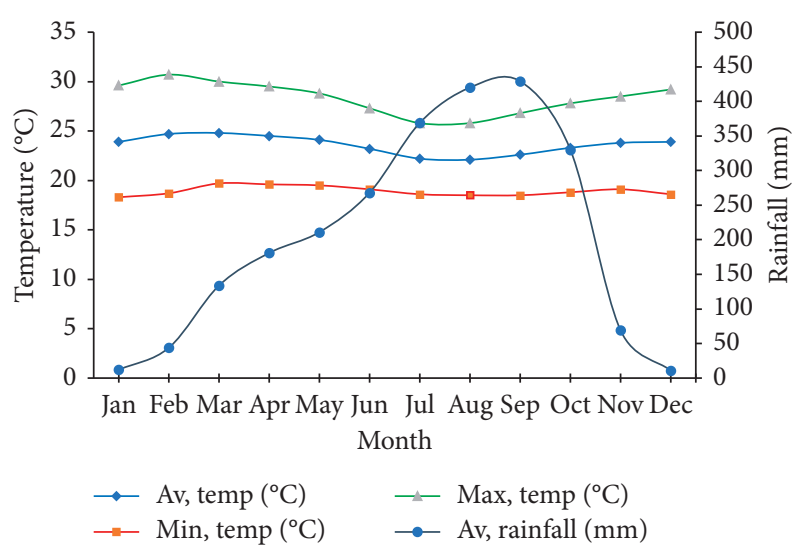

Figure 2: Climatic diagram of study area.

\section{Results and Discussion}

\subsection{Morphological Properties}

3.1.1. Soil Color. Morphological characteristics of the various soils (Table 3 ) show a wide range of colors in terms of value and chroma. Profile 1 , with a cambic ( $\mathrm{Bw}$ ) horizon, has a moist hue of 10YR throughout the profile except in the $\mathrm{Bw}_{2}$ horizon where the moist hue is 2.5YR. The $\mathrm{Bw}_{2}$ horizon also has a moist hue of $5 \mathrm{Y}$ as inclusions. From the Ap to the $\mathrm{Bw}_{1}$ horizon, the colors change from dark brown through brown to yellowish brown. The heterogeneity in terms of color observed in the $\mathrm{Bw}_{2}$ horizon (grayish red, pale orange, dull yellow orange, and bright yellowish brown) is associated with the influence of chemical weathering on the parent material, while that of the surface horizon is mainly due to organic matter. The $\mathrm{Bw}_{3}$ and $\mathrm{Cr}$ horizons are dominated by a bright yellowish brown color. In the dry state, profile 1 has hues of 5YR, 7.5YR, and 10YR from surface to subsurface horizons, with generally higher values and lower chroma compared to the corresponding horizon colors in moist state.

All the other profiles located within the plain (profiles 2, 3,4 , and 5) have a moist hue of 7.5YR and a dry hue of 10YR. However, the colors in the various horizons were greatly influenced either by organic matter accumulation or mottling. The mottles were observed to have a very wide range of colors within a particular soil profile. Profile 2, classified as a Humic Gleysol, has an abrupt moist color change from the surface Ah horizon (black) to subsurface horizons (brownish gray (E) and bright brown (Bt)), in conformity with soils of this reference soil group. Compared to the moist colors of profile 2, the color values in the dry state are generally higher. The gleyic color patterns of profile 2 are mainly due to oxidation-reducing conditions resulting from the fluctuations of the water table, mostly in subsurface layers. In the E horizon of profile 2, soil color changes instantaneously from gray to reddish brown when exposed to air, giving rise to oximorphic colors. Oximorphic conditions in profile 2 are observed in the dry season during which the water table drops and surface soil cracks, giving way for oxygen to freely circulate in parts of the profile. Profile 3, classified as a Gleyic Luvisol, shows a uniform color change from brown in the A horizon to dull brown and bright brown in subsurface horizons. The surface color appears to be influenced by organic matter from the forest vegetation, while the subsurface horizon colors show a gleyic pattern in the Btg and BCtg horizons; this as a result of water movements within this part of the soil profile. In profile 4, color is less influenced by gleyic conditions. Instead, the color pattern appears to be influenced by the presence of buried horizons. The moist color values did not follow any regular pattern from surface to subsurface horizons. Profile 5 surface (Ap) horizon has a brownish black moist color apparently associated with the accumulation of soil organic matter. The $\mathrm{AB}$ horizon has a bright brown moist color, while the BCt horizon has a brown color (moist). The underlying $\mathrm{Cg}$ horizons show gleyic color patterns with color values generally higher in the dry state compared to corresponding horizons in the moist state.

3.1.2. Soil Structure and Consistence. Profile 1 has granular structure in the Ap horizon and subangular blocky in subsurface horizons. The granular structure of surface horizons is associated with bioturbation by soil fauna and plant roots, especially where biological activity is high. Some parts of the $\mathrm{Bw}_{3}$ horizon of profile 1 show a blocky structure, associated with its expanding clay contents. The consistence (moist) varies from friable in the $\mathrm{A}$ and $\mathrm{AB}$ horizons to firm in the cambic $(\mathrm{Bw})$ horizons and then to weak in $\mathrm{Cr}$ horizons where the soil is very friable. Consistence (wet) is very sticky and very plastic in horizons with blocky structures, and nonsticky and nonplastic in horizons with granular structures. Occurrence of krotovinas in the first five horizons of this profile and their dominance in the $\mathrm{Bw}_{3}$ horizon indicate transportation and accumulation of material (mainly organic matter) from one horizon to another. Weathered quartz veins traverse from $\mathrm{Bw}_{2}$ to $\mathrm{Cr}_{2}$ horizons in a $\mathrm{NW}$ to $\mathrm{SE}$ direction, with pressure faces of roots visible throughout the profile. Profile 2 structure is granular in the Ah horizon; blocky in the $\mathrm{E}, \mathrm{Bt}$, and Btg horizons; and granular in the $\mathrm{C}$ horizons. The consistence ranges from hard to very hard (dry) and friable to firm (moist). Field observations reveal that the soil surface of this profile cracks during the dry season forming medium $(1-2 \mathrm{~cm})$ to wide $(3-5 \mathrm{~cm})$ cracks, giving rise to a very hard structure, a kind similar to that of Vertisols which makes tillage with common tools such as hoes difficult. This cracking phenomenon is apparently associated with the presence of swelling-type clay minerals formed through neosynthesis processes, favored by the prevailing environmental conditions (in a depositional basin environment). Profile 3 has structure and consistence in the moist and dry states similar to those of profile 2. However, the consistence (wet) of profile 3, mostly very sticky and very plastic, is associated with the high contents of its swelling clays. Structure and consistence in profiles 4 and 5 do not show any regular pattern from surface to subsurface horizons. Here texture is more determinant as sandy horizons (mostly BC and C) generally have a granular, weak, or a subangular blocky structure that easily fragments in the moist 
TABle 2: Description of study sites and classification of representative soil profiles.

\begin{tabular}{|c|c|c|c|c|c|}
\hline $\begin{array}{l}\text { Site } \\
\text { characteristics }\end{array}$ & Bamia series & Santchou series & Lelem series & Ntengie series & Bamengwi series \\
\hline $\begin{array}{l}\text { Geographical } \\
\text { coordinates }\end{array}$ & $\begin{array}{l}\text { Lat: } 05^{\circ} 17^{\prime} 51.5^{\prime \prime} \mathrm{N} \\
\text { Long: } 09^{\circ} 55^{\prime} 00.9^{\prime \prime} \mathrm{E}\end{array}$ & $\begin{array}{l}\text { Lat: } 05^{\circ} 16^{\prime} 23.5^{\prime \prime} \mathrm{N}, \\
\text { Long: } 09^{\circ} 58^{\prime} 26.0^{\prime \prime} \mathrm{E}\end{array}$ & $\begin{array}{l}\text { Lat: } 05^{\circ} 12^{\prime} 02.5^{\prime \prime} \mathrm{N} \\
\text { Long: } 09^{\circ} 59^{\prime} 54.0^{\prime \prime} \mathrm{E}\end{array}$ & $\begin{array}{l}\text { Lat: } 05^{\circ} 21^{\prime} 59.1^{\prime \prime} \mathrm{N} \\
\text { Long: } 10^{\circ} 00^{\prime} 27.9^{\prime \prime} \mathrm{E}\end{array}$ & $\begin{array}{l}\text { Lat: } 05^{\circ} 15^{\prime} 03.09^{\prime \prime} \mathrm{N} \text {, } \\
\text { Long: } 10^{\circ} 05^{\prime} 22.77^{\prime \prime} \mathrm{E}\end{array}$ \\
\hline $\begin{array}{l}\text { Land use/ } \\
\text { vegetation }\end{array}$ & $\begin{array}{l}\text { Intensely cultivated } \\
\text { farmland dominated by } \\
\text { mixed crops, including } \\
\text { cocoa, cocoyam, } \\
\text { plantain, oil palm, and } \\
\text { maize }\end{array}$ & $\begin{array}{l}\text { Uncultivated } \\
\text { grassland }\end{array}$ & $\begin{array}{l}\text { Uncultivated patch } \\
\text { (relics) of gallery } \\
\text { forest, having wild } \\
\text { palms, lianas, mixed } \\
\text { trees, shrubs, and } \\
\text { grass }\end{array}$ & $\begin{array}{l}\text { Cultivated farmland } \\
\text { with mixed crops, } \\
\text { including maize, sweet } \\
\text { potato, cowpea, okra, } \\
\text { huckleberry, and } \\
\text { pepper }\end{array}$ & $\begin{array}{l}\text { Cultivated farmland } \\
\text { with mixed perennial } \\
\text { crops, including oil } \\
\text { palm, cocoa, coffee, } \\
\text { banana, and plantain }\end{array}$ \\
\hline $\begin{array}{l}\text { Soil } \\
\text { management } \\
\text {-Tillage type } \\
\text {-Fertilization }\end{array}$ & $\begin{array}{c}\text { Minimum tillage } \\
\text { Occasional fertilization }\end{array}$ & $\begin{array}{l}\text { None } \\
\text { None }\end{array}$ & $\begin{array}{l}\text { None } \\
\text { None }\end{array}$ & $\begin{array}{l}\text { Conventional tillage } \\
\text { Regular fertilization }\end{array}$ & $\begin{array}{l}\text { Minimum tillage } \\
\text { Occasional } \\
\text { fertilization }\end{array}$ \\
\hline Physiography & $\begin{array}{l}\text { Foot slope, } 2-5 \% \\
\text { (strongly sloping), } \\
\text { medium-gradient hill } \\
\text { on straight concave } \\
\text { slope, good external } \\
\text { drainage and moderate } \\
\text { internal drainage. } \\
\text { Piedmont of the } \\
\text { escarpment which } \\
\text { limits the plain }\end{array}$ & $\begin{array}{l}\text { Plain, } 0 \% \text { (flat } \\
\text { terrain), poor } \\
\text { external drainage } \\
\text { and moderate } \\
\text { internal drainage }\end{array}$ & $\begin{array}{l}\text { Plain, almost flat } \\
\text { terrain }(0-1 \%) \text {, good } \\
\text { external drainage and } \\
\text { moderate internal } \\
\text { drainage }\end{array}$ & $\begin{array}{c}\text { Plain, flat terrain } \\
(0-1 \%) \text {, good external } \\
\text { and internal drainage }\end{array}$ & $\begin{array}{c}\text { Plain, flat terrain } \\
(0-1 \%) \text {, good external } \\
\text { drainage and } \\
\text { moderate internal } \\
\text { drainage }\end{array}$ \\
\hline Relief/elevation & Foot slope, $751 \mathrm{~m}$ asl & Plain, $711 \mathrm{~m}$ asl & Plain, $716 \mathrm{~m}$ asl & Plain, $723 \mathrm{~m}$ asl & Plain, $740 \mathrm{~m}$ asl \\
\hline Erosion & $\begin{array}{l}\text { Signs of slight geologic } \\
\text { erosion with presence of } \\
\text { gentle rills on soil } \\
\text { surface } \\
\end{array}$ & No signs of erosion & No signs of erosion & No signs of erosion & No signs of erosion \\
\hline Parent material & Granite & $\begin{array}{l}\text { Alluvial sediments } \\
\text { (for subsurface soil) } \\
\text { and organic matter } \\
\text { (for surface layer) }\end{array}$ & Alluvial sediments & Alluvial sediments & Alluvial sediments \\
\hline $\begin{array}{l}\text { Soil moisture } \\
\text { regime }\end{array}$ & Udic & Udic/aquic & Udic/aquic & Udic/aquic & Udic/aquic \\
\hline $\begin{array}{l}\text { Soil temperature } \\
\text { regime }\end{array}$ & Isohyperthermic & Isohyperthermic & Isohyperthermic & Isohyperthermic & Isohyperthermic \\
\hline $\begin{array}{l}\text { Soil } \\
\text { classification: } \\
\text { IUSS working } \\
\text { group WRB, } \\
\text { [58] }\end{array}$ & Eutric Cambisol & $\begin{array}{l}\text { Abruptic Gleysol } \\
\text { (Humic) }\end{array}$ & $\begin{array}{l}\text { Endoclayic Luvisol } \\
\text { (Gleyic) }\end{array}$ & Humi-Dystric Fluvisol & $\begin{array}{l}\text { Gleyi-Humic Fluvisol } \\
\text { (Eutric) }\end{array}$ \\
\hline $\begin{array}{l}\text { Soil } \\
\text { classification: } \\
\text { Soil survey staff } \\
\text { [59] }\end{array}$ & Typic Eutrudepts & Mollic Endoaquents & Oxyaquic Paleudalfs & Oxyaquic Udifluvents & Mollic Udifluvents \\
\hline
\end{tabular}

state. The consistence of the $\mathrm{Cg}$ horizons of profiles 4 and 5 was either loose or friable (moist) and nonplastic (wet).

\subsection{Physical Properties}

3.2.1. Bulk Density. Bulk density (BD) distribution within the different profiles shows erratic functions (Figure 4), associated with the differences in the nature and composition of the sedimentary parent materials and the variation in SOC contents. A negative and significant correlation exists between $\mathrm{BD}$ and SOC $(r=-0.648, p<0.01)$, indicating that BD increases with decrease in SOC contents. The highest BDs $\left(>1.30 \mathrm{Mg} \mathrm{m}^{-3}\right)$ occur in subsurface horizons of profiles 1 (Bw horizon), profile 2 (Btg and C horizons), and profile 5 (BCt and Cg horizons), while the lowest $\mathrm{BD}\left(0.66 \mathrm{Mg} \mathrm{m}^{-3}\right)$ occurs in the surface $(\mathrm{Ah})$ horizon of profile 2 resulting from its high organic matter contents. All the other profiles have surface bulk density of about $1 \mathrm{Mg} \mathrm{m}^{-3}$.

3.2.2. Particle Size Distribution (Texture). Soil texture varies across the different sites and within some profiles (Table 4, Figure 4). Profile 1 has textures ranging from clayey to loam. Profile 2 with textures ranging from heavy clay to loam 

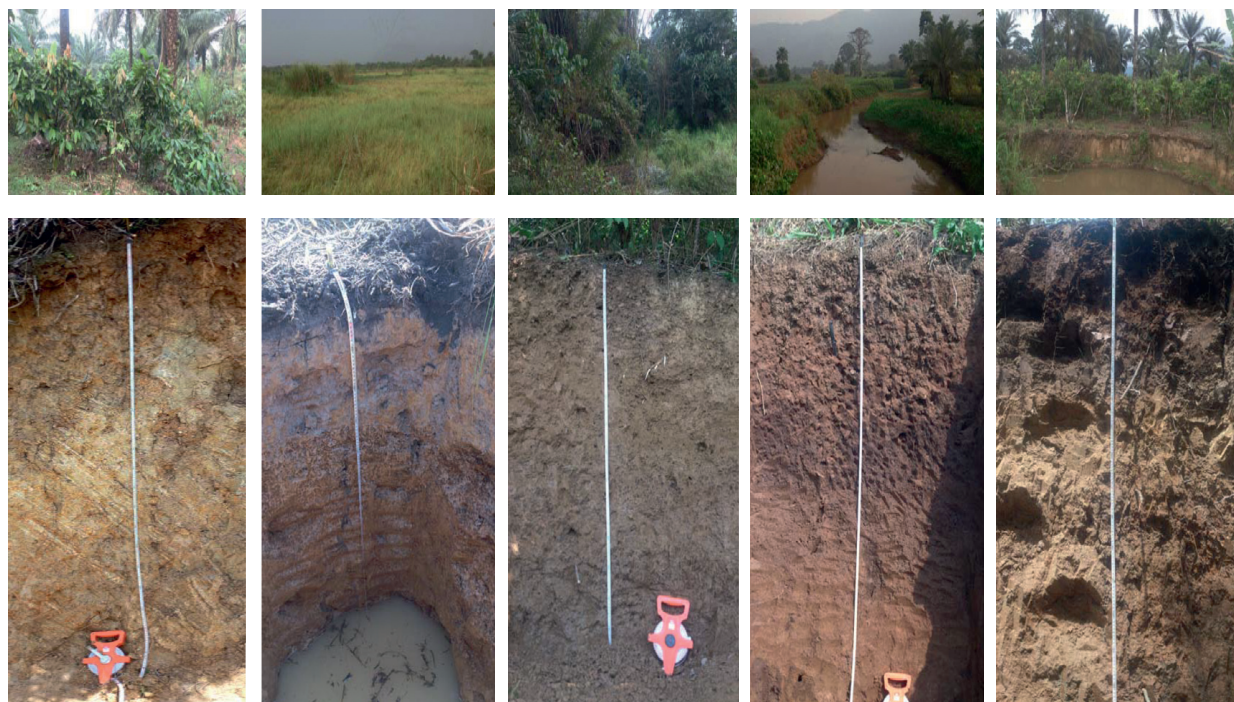

Bamia profile

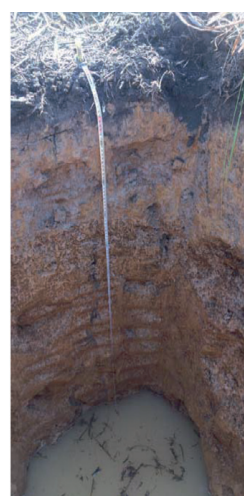

Santchou profile

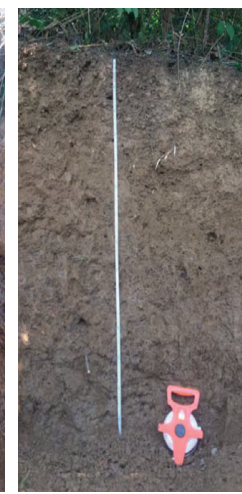

Lelem profile

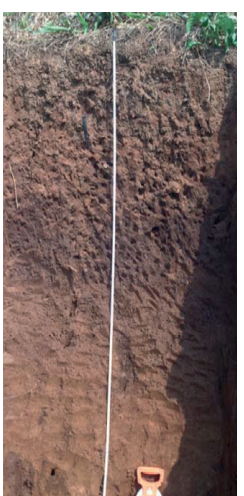

Ntengie profile

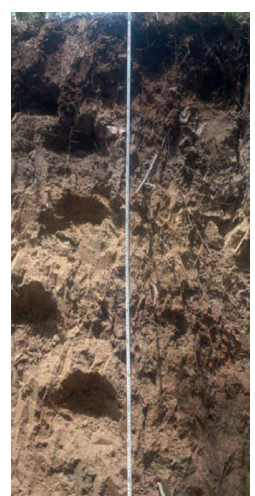

Bamengwi profile

FIGURE 3: Landscapes and vegetation of different sampling sites and their corresponding soil profiles.

indicates that it originates from different parent materials. The surface Ah horizon has a loamy texture with a high silt/ clay ratio of 1.23 , while the underlying $2 \mathrm{Bt} / \mathrm{E}$ horizon has an abrupt texture of heavy clay with a very low silt/clay ratio of 0.23 indicating that it has formed from a more advanced weathered material [66] compared to the Ah horizon, apparently dominantly formed from the accumulation of OM originating from the prevailing grassland vegetation. The high sand/silt ratios and very high sand contents $(>46 \%)$ at $>90 \mathrm{~cm}$ depths are indicative of differential sedimentation following Stokes' law. Profile 3 with clayey textural class throughout the profile is in agreement with the advanced weathering stage of the profile as indicated by the low silt/ clay ratio $(\leq 0.76)$ corroborated by the development of argillic $(\mathrm{Bt})$ horizons. The textures in profile 4 range from clay loam in the surface horizon to sandy clay loam in the $\mathrm{AB}, \mathrm{Cg}$, and $2 \mathrm{AB}$ horizons, and clay loam in the $2 \mathrm{Btg}$ and $2 \mathrm{BC}$ horizons. Stratigraphic breaks indicative of different provenance of the parent materials are indicated by sand contents, sand/silt ratios, and $\mathrm{BD}$. Textures in profile 5 vary from loam through sandy loam to clay loam.

This profile is the one developed from the most varied parent material as indicated by erratic depth functions of sand, sand/silt ratios, and silt/clay ratios. The very high silt/ clay ratios (>1.4) in all (except the $\mathrm{BCt}$ ) horizons of this soil indicate that the deposited materials in the different horizons are of recent age with a low degree of weathering. There was a significant and negative correlation between sand and clay content $(r=-0.855, p<0.01)$ and also between sand and clay ratio $(r=-0.784, p<0.01)$, confirming the classical relationship existing between sand and clay. The sand/silt ratio had a similar trend to sand content with a strong and significant correlation observed between them $(r=0.855$, $p<0.01)$. This shows that the sand/silt ratio can be used as an index in qualifying weathering trends in these soils, whereby high sand/silt ratios indicate low weathering intensities (less developed soils), while low sand/silt ratios indicate materials with high weathering intensities (more developed soils) [67]. On the other hand, the silt/clay ratio gives an indication of the degree of weathering of parent materials [66-68], whereby soils with silt/clay ratios $<0.15$ are reported to have developed from highly weathered parent materials, while those with ratios $>0.15$ are reported to have developed from young parent materials with low degree of weathering [67]. Silt/clay ratios in the soils studied ranged between 0.23 and 2.45 for all horizons, indicating that they have developed from parent materials still at an initial weathering stage. However, the sharp differences in silt/clay ratio observed between different horizons of a particular soil profile are indicative of differences in the provenance and nature (composition) of the parent materials.

\subsection{Chemical Characteristics}

3.3.1. Soil Acidity and Electrical Conductivity. All the soils studied were generally acidic and have a net negative charge on the soil exchange complex. The trend in $\mathrm{pH}$ values is $\mathrm{pH}$ $\mathrm{H}_{2} \mathrm{O}>\mathrm{pH}-\mathrm{CaCl}_{2}>\mathrm{pH}-\mathrm{KCl}$ (Table 5). Profiles 2 and 3 are the most acidic with $\mathrm{pH}-\mathrm{H}_{2} \mathrm{O}$ values ranging between 4.5 and 5.0, followed by profiles 1 and 4 with $\mathrm{pH}-\mathrm{H}_{2} \mathrm{O}$ values of 5.2 to 5.8 , and lastly by profile 5 with $\mathrm{pH}-\mathrm{H}_{2} \mathrm{O}$ values 5.7 and 6.4. Profiles 1 and 2 do not exhibit any depth functions. However, in profiles 3, 4, and 5, pH values generally increase from surface to subsurface horizons. Exchangeable $\mathrm{Al}^{3+}$ and $\mathrm{H}^{+}$concentrations are highest in profile 2 followed by profile 3. Profile 2, with the humic Ah horizon, is strongly acidic with a $\mathrm{pH}-\mathrm{H}_{2} \mathrm{O}$ value of 4.8 and exchangeable $\mathrm{Al}^{3+}$ of 3.3 $\mathrm{cmol}_{\mathrm{c}} \mathrm{kg}^{-1}$, consistent with the high solubility of $\mathrm{Al}^{3+}$ at low $\mathrm{pH}$ values.

The electrical conductivity of all the soils is very low $\left(<0.05 \mathrm{dSm}^{-1}\right)$, indicating that these soils are nonsaline. The highest $\mathrm{EC}$ value was observed in surface horizons of profile 4 , apparently associated with addition of salts from fertilizers inputs. 
TABLE 3: Morphological characteristics of the soils.

\begin{tabular}{|c|c|c|c|c|c|c|c|c|c|c|c|}
\hline \multirow[b]{2}{*}{ Horizon } & \multirow{2}{*}{$\begin{array}{l}\text { Depth } \\
(\mathrm{cm})\end{array}$} & \multicolumn{2}{|c|}{ Color } & \multirow[b]{2}{*}{ Structure } & \multicolumn{3}{|c|}{ Consistence } & \multirow[b]{2}{*}{ Voids } & \multirow{2}{*}{$\begin{array}{c}\text { Roots and } \\
\text { biological } \\
\text { features }\end{array}$} & \multirow{2}{*}{$\begin{array}{l}\text { Nodules/ } \\
\text { concretions }\end{array}$} & \multirow{2}{*}{$\begin{array}{c}\text { Boundary } \\
\text { characteristics }\end{array}$} \\
\hline & & Moist & Dry & & Dry & Moist & Wet & & & & \\
\hline \multicolumn{12}{|c|}{ Profile 1. Bamia series } \\
\hline Ap & $0-10$ & $10 Y R 3 / 3$ & 5 YR $5 / 2$ & GR & SHA & FRF & $\begin{array}{l}\text { VST } \\
\text { and } \\
\text { VPL }\end{array}$ & $\begin{array}{c}\text { Few } \mathrm{F} \text { and } \\
\mathrm{M}\end{array}$ & $\begin{array}{l}\text { Common } \\
\mathrm{F}, \mathrm{M}, \mathrm{C}, \mathrm{E}, \\
\text { and T }\end{array}$ & $\begin{array}{l}\text { VF quartz } \\
\text { grains }\end{array}$ & $\mathrm{C}$ and $\mathrm{S}$ \\
\hline $\mathrm{AB}$ & $10-24$ & 10YR 4/6 & $7.5 Y R 6 / 6$ & SB & HA & FRF & $\begin{array}{l}\text { VST } \\
\text { and } \\
\text { VPL }\end{array}$ & $\begin{array}{c}\text { Few } \mathrm{F} \text { and } \\
\mathrm{M}\end{array}$ & $\begin{array}{c}\text { Few } \mathrm{F} \text { and } \\
\mathrm{M}, \mathrm{E} \text {, and } \\
\mathrm{T}\end{array}$ & $\begin{array}{l}\text { VF quartz } \\
\text { grains }\end{array}$ & $\mathrm{D}$ and $\mathrm{S}$ \\
\hline $\mathrm{Bw}_{1}$ & $24-42$ & 10YR 5/6 & $7.5 Y R 6 / 4$ & $\mathrm{SB}$ & HA & FI & $\begin{array}{l}\text { VST } \\
\text { and } \\
\text { VPL }\end{array}$ & Few M & $\begin{array}{c}\text { Few } M \text { and } \\
\text { C, } \mathrm{T}\end{array}$ & $\begin{array}{l}\text { F quartz } \\
\text { grains }\end{array}$ & $\mathrm{D}$ and $\mathrm{S}$ \\
\hline $\mathrm{Bw}_{2}$ & $\begin{array}{c}42-72 / \\
90\end{array}$ & $\begin{array}{c}2.5 \text { YR 5/2 } \\
\text { (Matrix) } \\
5 Y 8 / 3 \\
\text { (inclusions) } \\
\text { 10YR 6/8 } \\
\text { (Inclusions) } \\
\text { 10YR 6/4 } \\
\text { (inclusions) }\end{array}$ & $\begin{array}{c}\text { 10YR } 7 / 3 \\
\text { (Matrix) } \\
10 Y R 7 / 6 \\
\text { (inclusions) } \\
10 \text { YR } 7 / 2 \\
\text { (inclusions) }\end{array}$ & $\mathrm{SB}$ & HA & FI & $\begin{array}{c}\text { ST } \\
\text { and } \\
\text { PL }\end{array}$ & Few C & $\begin{array}{l}\text { Very few } \\
\text { C, T }\end{array}$ & $\begin{array}{l}\text { M quarts } \\
\text { grains }\end{array}$ & $\mathrm{D}$ and $\mathrm{W}$ \\
\hline $\mathrm{Bw}_{3}$ & $\begin{array}{c}72 / \\
90-102\end{array}$ & $10 \mathrm{YR} 6 / 8$ & 7.5 YR $7 / 2$ & $\begin{array}{l}\mathrm{SB} \longrightarrow \mathrm{GR}, \\
\mathrm{BL} \text { in places }\end{array}$ & HA & FI & $\begin{array}{l}\text { SST } \\
\text { and } \\
\text { SPL }\end{array}$ & Few C & Very few C & $\begin{array}{l}\text { M quarts } \\
\text { grains }\end{array}$ & $\mathrm{D}$ and $\mathrm{W}$ \\
\hline $\mathrm{Cr}_{1}$ & $102-157$ & 10YR 6/8 & 10 YR $8 / 3$ & $\mathrm{SB} \longrightarrow \mathrm{GR}$ & VHA & $\mathrm{WE} \longrightarrow \mathrm{FR}$ & $\begin{array}{l}\text { NST } \\
\text { and } \\
\text { NPL }\end{array}$ & Very few C & $\begin{array}{c}\text { Very few } \\
\text { M }\end{array}$ & Common & $\mathrm{D}$ and $\mathrm{S}$ \\
\hline $\mathrm{Cr}_{2}$ & $157-215$ & 10YR $6 / 8$ & $10 \mathrm{YR} 8 / 3$ & $\mathrm{SB} \longrightarrow \mathrm{GR}$ & VHA & $\mathrm{WE} \longrightarrow \mathrm{FR}$ & $\begin{array}{l}\text { NST } \\
\text { and } \\
\text { NPL } \\
\end{array}$ & Very few C & Very few $\mathrm{F}$ & Common & $\mathrm{D}$ and $\mathrm{S}$ \\
\hline \multicolumn{12}{|c|}{ Profile 2. Santchou series } \\
\hline $\mathrm{Ah}$ & $0-12$ & 7.5 YR $2 / 1$ & $10 \mathrm{YR} 2 / 3$ & GR & HA & FR & $\begin{array}{l}\text { SST } \\
\text { and } \\
\text { NPL }\end{array}$ & $\begin{array}{l}\text { Many F } \\
\text { and M }\end{array}$ & $\begin{array}{l}\text { Common } \\
\mathrm{F}, \mathrm{M}, \mathrm{C}, \mathrm{E} \\
\text { and } \mathrm{T}\end{array}$ & $\mathrm{N}$ & A \\
\hline $2 \mathrm{Bt} / \mathrm{E}$ & $12-38$ & $\begin{array}{l}7.5 \text { YR } 6 / 1 \\
(\mathrm{E}) \\
7.5 \mathrm{YR} 5 / 6 \\
(\mathrm{Bt})\end{array}$ & $\begin{array}{c}\text { 10YR 6/3 } \\
(\mathrm{E}) \\
10 \mathrm{YR} 7 / 6 \\
(\mathrm{Bt})\end{array}$ & $\mathrm{BL}$ & VHA & FI & $\begin{array}{l}\text { VST } \\
\text { and } \\
\text { VPL }\end{array}$ & Few C & $\begin{array}{l}\text { Very few } \\
\text { C, T }\end{array}$ & $\begin{array}{l}\text { VF quartz } \\
\text { grains }\end{array}$ & $\mathrm{C}$ and $\mathrm{S}$ \\
\hline $2 \mathrm{E} / \mathrm{Bt}$ & $38-58$ & $\begin{array}{c}\text { 7.5YR 5/6 } \\
\text { (matrix) } \\
7.5 \text { YR 6/1 } \\
\text { (mottles) }\end{array}$ & $\begin{array}{c}\text { 10YR } 7 / 3 \\
\text { (matrix) } \\
\text { 10YR } 3 / 2 \\
\text { (mottles) }\end{array}$ & $\mathrm{BL}$ & VHA & FI & $\begin{array}{l}\text { VST } \\
\text { and } \\
\text { VPL }\end{array}$ & Few C & Very few F & $\begin{array}{l}\text { VF quartz } \\
\text { grains }\end{array}$ & $\mathrm{D}$ and $\mathrm{S}$ \\
\hline $2 \mathrm{Btg} 2$ & $58-90$ & $\begin{array}{c}7.5 \text { YR 5/6 } \\
\text { (matrix) } \\
7.5 \text { YR 6/2 } \\
\text { (mottles) }\end{array}$ & $\begin{array}{c}\text { 10YR 5/6 } \\
\text { (matrix) } \\
\text { 10YR 6/3 } \\
\text { (mottles) }\end{array}$ & $\mathrm{BL}$ & VHA & FI & $\begin{array}{l}\text { VST } \\
\text { and } \\
\text { VPL }\end{array}$ & $\mathrm{N}$ & Very few F & $\mathrm{N}$ & $\mathrm{D}$ and $\mathrm{S}$ \\
\hline $2 \mathrm{Btg} 3$ & $90-115$ & $\begin{array}{c}7.5 \text { YR } 5 / 6 \\
\text { (matrix) } \\
7.5 \text { YR 6/2 } \\
\text { (mottles) }\end{array}$ & $\begin{array}{c}\text { 10YR } 7 / 2 \\
\text { (matrix) } \\
10 \text { YR } 7 / 6 \\
\text { (mottles) }\end{array}$ & $\mathrm{BL}$ & VHA & FI & $\begin{array}{l}\text { VST } \\
\text { and } \\
\text { VPL }\end{array}$ & $\mathrm{N}$ & $\mathrm{N}$ & $\mathrm{N}$ & $\mathrm{D}$ and $\mathrm{S}$ \\
\hline $2 \mathrm{C} 1$ & $115-167$ & $\begin{array}{c}7.5 \text { YR 5/8 } \\
\text { (matrix) } \\
7.5 \text { YR 4/3 } \\
\text { (mottles) }\end{array}$ & $\begin{array}{c}\text { 10YR } 7 / 2 \\
\text { (matrix) } \\
10 \text { YR } 7 / 6 \\
\text { (mottles) }\end{array}$ & GR & HA & $\mathrm{WE} \longrightarrow \mathrm{FR}$ & $\begin{array}{l}\text { SST } \\
\text { and } \\
\text { SPL }\end{array}$ & $\mathrm{N}$ & $\mathrm{N}$ & $\mathrm{N}$ & $\mathrm{D}$ and $\mathrm{S}$ \\
\hline $2 \mathrm{C} 2$ & $167-205$ & $\begin{array}{c}7.5 \text { YR } 5 / 8 \\
\text { (matrix) } \\
7.5 \text { YR 6/2 } \\
\text { (mottles) }\end{array}$ & $\begin{array}{c}\text { 10YR } 7 / 3 \\
\text { (matrix) } \\
10 \mathrm{YR} 7 / 6 \\
\text { (mottles) }\end{array}$ & GR & $\mathrm{HA}$ & $\mathrm{WE} \longrightarrow \mathrm{FR}$ & $\begin{array}{l}\text { SST } \\
\text { and } \\
\text { SPL }\end{array}$ & $\mathrm{N}$ & $\mathrm{N}$ & $\mathrm{N}$ & $\mathrm{D}$ and $\mathrm{S}$ \\
\hline
\end{tabular}


TABle 3: Continued.

\begin{tabular}{|c|c|c|c|c|c|c|c|c|c|c|c|}
\hline \multirow[b]{2}{*}{ Horizon } & \multirow{2}{*}{$\begin{array}{l}\text { Depth } \\
(\mathrm{cm})\end{array}$} & \multicolumn{2}{|c|}{ Color } & \multirow[b]{2}{*}{ Structure } & \multicolumn{3}{|c|}{ Consistence } & \multirow[b]{2}{*}{ Voids } & \multirow{2}{*}{$\begin{array}{l}\text { Roots and } \\
\text { biological } \\
\text { features }\end{array}$} & \multirow{2}{*}{$\begin{array}{l}\text { Nodules/ } \\
\text { concretions }\end{array}$} & \multirow{2}{*}{$\begin{array}{c}\text { Boundary } \\
\text { characteristics }\end{array}$} \\
\hline & & Moist & Dry & & Dry & Moist & Wet & & & & \\
\hline \multicolumn{12}{|c|}{ Profile 3. Lelem series } \\
\hline A & $0-18$ & $7.5 Y R \quad 4 / 4$ & 10 YR $5 / 4$ & $\mathrm{SB} \longrightarrow \mathrm{GR}$ & HA & FR & $\begin{array}{c}\text { ST } \\
\text { and } \\
\text { PL }\end{array}$ & $\begin{array}{c}\text { Many F, M } \\
\text { and C }\end{array}$ & $\begin{array}{l}\text { Many F, } \\
\text { M, C, T }\end{array}$ & $\mathrm{N}$ & $\mathrm{C}$ and $\mathrm{S}$ \\
\hline Bt1 & $18-43$ & 7.5 YR 5/4 & 10 YR $5 / 6$ & $\mathrm{SB} \longrightarrow \mathrm{GR}$ & VHA & FI & $\begin{array}{l}\text { VST } \\
\text { and } \\
\text { VPL }\end{array}$ & $\begin{array}{l}\text { Common } \\
\text { F, M and C }\end{array}$ & $\begin{array}{l}\text { Many F, } \\
M, C, T\end{array}$ & $\mathrm{~N}$ & $\mathrm{D}$ and $\mathrm{S}$ \\
\hline Bt2 & $43-73$ & $7.5 Y R 5 / 4$ & $10 Y R 5 / 6$ & $\mathrm{AB}$ & VHA & FI & $\begin{array}{l}\text { VST } \\
\text { and } \\
\text { VPL }\end{array}$ & $\begin{array}{l}\text { Common } \\
\text { F, M and C }\end{array}$ & $\begin{array}{c}\text { Few F, M, } \\
\text { C, T }\end{array}$ & $\mathrm{N}$ & $\mathrm{D}$ and $\mathrm{S}$ \\
\hline Btg & $\begin{array}{c}73-118 / \\
134\end{array}$ & $\begin{array}{c}\text { 7.5YR 5/4 } \\
\text { (Matrix) } \\
7.5 \text { YR 3/3 } \\
\text { (mottles) }\end{array}$ & $\begin{array}{c}\text { 10YR 6/4 } \\
\text { (Matrix) } \\
\text { 10YR 4/2 } \\
\text { (mottles) }\end{array}$ & SB & VHA & FI & $\begin{array}{l}\text { VST } \\
\text { and } \\
\text { VPL }\end{array}$ & $\begin{array}{l}\text { Few M } \\
\text { and } C\end{array}$ & $\begin{array}{l}\text { Very few F, } \\
\text { M, C, T }\end{array}$ & $\mathrm{N}$ & $\mathrm{D}$ and $\mathrm{W}$ \\
\hline BCtg & $\begin{array}{c}118 / \\
134-175\end{array}$ & $\begin{array}{c}7.5 \text { YR 6/2 } \\
\text { (matrix) } \\
7.5 \text { YR } 3 / 2 \\
\text { (mottles) } \\
7.5 \text { YR 5/6 } \\
\text { (mottles) }\end{array}$ & $\begin{array}{c}\text { 10YR 6/4 } \\
\text { (matrix) } \\
\text { 10YR 5/6 } \\
\text { (mottles) } \\
\text { 10YR 6/8 } \\
\text { (mottles) }\end{array}$ & $\mathrm{SB} \longrightarrow \mathrm{GR}$ & VHA & FI & $\begin{array}{l}\text { VST } \\
\text { and } \\
\text { VPL }\end{array}$ & $\begin{array}{l}\text { Few M } \\
\text { and C }\end{array}$ & $\begin{array}{l}\text { Very few F, } \\
\text { M, C, T }\end{array}$ & $\mathrm{N}$ & $\mathrm{D}$ and $\mathrm{W}$ \\
\hline \multicolumn{12}{|c|}{ Profile 4. Ntengie series } \\
\hline Ap & $0-27$ & $7.5 Y R 3 / 3$ & 10YR $4 / 4$ & SB & VHA & FI & $\begin{array}{l}\text { SST } \\
\text { and } \\
\text { SPL }\end{array}$ & $\begin{array}{c}\text { Many F, M } \\
\text { and C }\end{array}$ & $\begin{array}{c}\text { Many F, } \\
\text { M, T }\end{array}$ & $\mathrm{N}$ & $\mathrm{G}$ and $\mathrm{S}$ \\
\hline $\mathrm{AB}$ & $27-50$ & 7.5 YR 5/6 & $10 \mathrm{YR} 4 / 4$ & $\mathrm{SB} \longrightarrow \mathrm{GR}$ & HA & FI & $\begin{array}{l}\text { SST } \\
\text { and } \\
\text { SPL }\end{array}$ & $\begin{array}{l}\text { Many F } \\
\text { and } \mathrm{M}\end{array}$ & $\begin{array}{l}\text { Many F, } \\
\text { M, C, T }\end{array}$ & $\mathrm{N}$ & $\mathrm{D}$ and $\mathrm{S}$ \\
\hline $\mathrm{Cg}$ & $50-82$ & $\begin{array}{c}\text { 7.5YR 4/6 } \\
\text { (matrix) } \\
7.5 \text { YR 5/8 } \\
\text { (mottles) }\end{array}$ & $\begin{array}{c}\text { 10YR 4/6 } \\
\text { (matrix) } \\
\text { 10YR 5/6 } \\
\text { (mottles) }\end{array}$ & GR & LO & LO & $\begin{array}{l}\text { NST } \\
\text { and } \\
\text { NPL }\end{array}$ & $\begin{array}{l}\text { Many F } \\
\text { and M }\end{array}$ & $\begin{array}{c}\text { Few } \mathrm{F} \text { and } \\
\mathrm{M}\end{array}$ & $\mathrm{N}$ & $\mathrm{C}$ and $\mathrm{S}$ \\
\hline $2 \mathrm{AB}$ & $82-116$ & 7.5 YR $4 / 3$ & $10 \mathrm{YR} 3 / 4$ & SB & HA & FI & $\begin{array}{c}\text { ST } \\
\text { and } \\
\text { PL }\end{array}$ & $\begin{array}{l}\text { Few M } \\
\text { and } C\end{array}$ & $\begin{array}{c}\text { Few } \mathrm{F} \text { and } \\
\mathrm{M}\end{array}$ & $\mathrm{N}$ & $\mathrm{D}$ and $\mathrm{S}$ \\
\hline 2Btg & $116-160$ & 7.5 YR $5 / 4$ & $10 \mathrm{YR} 4 / 6$ & $\mathrm{AB}$ & HA & FI & $\begin{array}{l}\text { ST } \\
\text { and } \\
\text { PL }\end{array}$ & $\begin{array}{l}\text { Few M } \\
\text { and } C\end{array}$ & $\begin{array}{c}\text { Few } \mathrm{F} \text { and } \\
\mathrm{M}\end{array}$ & $\mathrm{N}$ & $\mathrm{C}$ and $\mathrm{S}$ \\
\hline $2 \mathrm{BC}$ & $160-210$ & $7.5 Y R 5 / 6$ & $10 Y R 5 / 6$ & $\mathrm{SB} \longrightarrow \mathrm{GR}$ & HA & FI & $\begin{array}{l}\text { SST } \\
\text { and } \\
\text { SPL }\end{array}$ & $\begin{array}{l}\text { Few M } \\
\text { and } C\end{array}$ & $\begin{array}{c}\text { Few } \mathrm{F} \text { and } \\
\mathrm{M}\end{array}$ & $\mathrm{N}$ & $\mathrm{D}$ and $\mathrm{S}$ \\
\hline \multicolumn{12}{|c|}{ Profile 5. Bamengwi series } \\
\hline Ap & $0-25$ & $7.5 Y R \quad 3 / 2$ & 10 YR $5 / 4$ & $\mathrm{SB} \longrightarrow \mathrm{GR}$ & VHA & FR & $\begin{array}{l}\text { ST } \\
\text { and } \\
\text { PL }\end{array}$ & $\begin{array}{c}\text { Many F, M } \\
\text { and C }\end{array}$ & $\begin{array}{l}\text { Many F, } \\
\text { M, T and } \\
\text { few E }\end{array}$ & $\mathrm{N}$ & $\mathrm{G}$ and $\mathrm{S}$ \\
\hline $\mathrm{AB}$ & $25-44$ & $7.5 Y R 5 / 6$ & 10YR $6 / 4$ & GR & SSH & FR & $\begin{array}{l}\text { SST } \\
\text { and } \\
\text { SPL }\end{array}$ & $\begin{array}{c}\text { Many F } \\
\text { and M }\end{array}$ & $\begin{array}{c}\text { Many F, } \\
\text { M, C, T, } \\
\text { and few B }\end{array}$ & $\mathrm{N}$ & $\mathrm{G}$ and $\mathrm{S}$ \\
\hline $\mathrm{BCt}$ & $41-66$ & $7.5 Y R \quad 4 / 4$ & $10 \mathrm{YR} 6 / 3$ & BL & VHA & FI & $\begin{array}{l}\text { VST } \\
\text { and } \\
\text { VPL }\end{array}$ & $\begin{array}{l}\text { Many F } \\
\text { and M }\end{array}$ & $\begin{array}{c}\text { Few F and } \\
M\end{array}$ & $\mathrm{~N}$ & $\mathrm{C}$ and $\mathrm{W}$ \\
\hline $2 \mathrm{Cg} 1$ & $66-102$ & $\begin{array}{c}\text { 10YR 7/6 } \\
\text { (matrix) } \\
7.5 \text { YR } 7 / 8 \\
\text { (mottles) }\end{array}$ & $\begin{array}{c}\text { 10YR } 7 / 3 \\
\text { (matrix) } \\
\text { 10YR 6/8 } \\
\text { (mottles) }\end{array}$ & WE SB & SHA & LO & $\begin{array}{l}\text { NST } \\
\text { and } \\
\text { NPL }\end{array}$ & $\begin{array}{l}\text { Few M } \\
\text { and C }\end{array}$ & $\begin{array}{c}\text { Few } \mathrm{F} \text { and } \\
\mathrm{M}\end{array}$ & $\mathrm{N}$ & $\mathrm{C}$ and $\mathrm{W}$ \\
\hline $3 \mathrm{Cg} 2$ & $102-134$ & $\begin{array}{c}\text { 7.5YR 6/3 } \\
\text { (matrix) } \\
7.5 \text { YR 6/6 } \\
\text { (mottles) }\end{array}$ & $\begin{array}{c}\text { 10YR 6/4 } \\
\text { (matrix) } \\
\text { 10YR 7/8 } \\
\text { (mottles) }\end{array}$ & $\mathrm{SB} \longrightarrow \mathrm{GR}$ & VHA & FR & $\begin{array}{c}\text { ST } \\
\text { and } \\
\text { PL }\end{array}$ & $\begin{array}{l}\text { Few M } \\
\text { and } C\end{array}$ & $\begin{array}{c}\text { Few } \mathrm{F} \text { and } \\
\mathrm{M}\end{array}$ & $\mathrm{N}$ & $\mathrm{D}$ and $\mathrm{S}$ \\
\hline
\end{tabular}


TABLE 3: Continued.

\begin{tabular}{|c|c|c|c|c|c|c|c|c|c|c|c|}
\hline \multirow{2}{*}{ Horizon } & \multirow{2}{*}{$\begin{array}{l}\text { Depth } \\
(\mathrm{cm})\end{array}$} & \multicolumn{2}{|c|}{ Color } & \multirow[b]{2}{*}{ Structure } & \multicolumn{3}{|c|}{ Consistence } & \multirow[b]{2}{*}{ Voids } & \multirow{2}{*}{$\begin{array}{c}\text { Roots and } \\
\text { biological } \\
\text { features }\end{array}$} & \multirow{2}{*}{$\begin{array}{l}\text { Nodules/ } \\
\text { concretions }\end{array}$} & \multirow{2}{*}{$\begin{array}{c}\text { Boundary } \\
\text { characteristics }\end{array}$} \\
\hline & & Moist & Dry & & Dry & Moist & Wet & & & & \\
\hline $4 \mathrm{Cg} 3$ & $134-162$ & $\begin{array}{c}\text { 7.5YR 6/4 } \\
\text { (matrix) } \\
7.5 \text { YR 5/8 } \\
\text { (mottles) }\end{array}$ & $\begin{array}{c}\text { 10YR } 7 / 3 \\
\text { (matrix) } \\
\text { 10YR } 7 / 8 \\
\text { (mottles) }\end{array}$ & $\mathrm{SB} \longrightarrow \mathrm{GR}$ & SSH & FR & $\begin{array}{l}\text { SST } \\
\text { and } \\
\text { SPL }\end{array}$ & $\begin{array}{l}\text { Few M } \\
\text { and C }\end{array}$ & $\begin{array}{c}\text { Few } F \text { and } \\
M\end{array}$ & $\mathrm{~N}$ & $\mathrm{D}$ and $\mathrm{S}$ \\
\hline $5 \mathrm{Cg} 4$ & $162-205$ & $\begin{array}{c}7.5 \text { YR 6/2 } \\
\text { (matrix) } \\
7.5 \text { YR 5/8 } \\
\text { (mottles) }\end{array}$ & $\begin{array}{c}\text { 10YR } 7 / 3 \\
\text { (matrix) } \\
\text { 10YR 7/8 } \\
\text { (mottles) }\end{array}$ & $\mathrm{SB} \longrightarrow \mathrm{GR}$ & VHA & FR & $\begin{array}{l}\text { SST } \\
\text { and } \\
\text { SPL }\end{array}$ & Very few F & $\begin{array}{c}\text { Few } F \text { and } \\
M\end{array}$ & $\mathrm{~N}$ & $\mathrm{D}$ and $\mathrm{S}$ \\
\hline
\end{tabular}

Note. BL blocky, SB subangular blocky, GR granular, AB angular blocky, SB $\longrightarrow$ GR subangular blocky parting to granular, SHA slightly hard, HA hard, VHA very hard, SSH soft to slightly hard, WE weak, FR friable, FI firm, FRF friable to firm, LO loose, ST sticky, SST lightly sticky, PL plastic, SPL slightly plastic, VST very sticky, VPL very plastic, NST nonsticky, NPL nonplastic. For boundary, G gradual $(5-15 \mathrm{~cm}), \mathrm{A}$ abrupt, $(0-2 \mathrm{~cm}), \mathrm{C}$ clear $(2-5 \mathrm{~cm}), \mathrm{D}$ diffuse $(>15 \mathrm{~cm})$, S smooth, W wavy. For roots and biological features, F few, M many, C common (for abundance of roots), E earthworm channels, B burrows, Tant channels. For voids, F fine, M medium, C coarse, N none. For nodules and concretions, N none, F few, VF very few. Source: FAO [60].

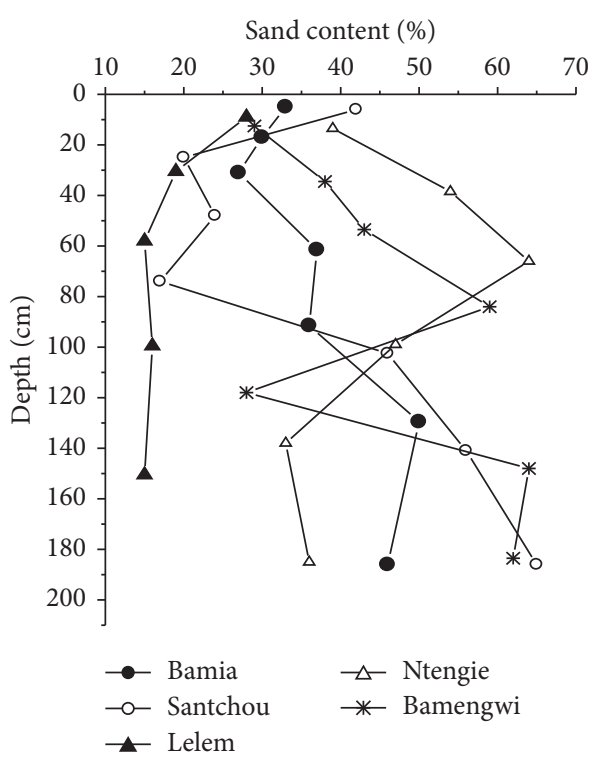

(a)

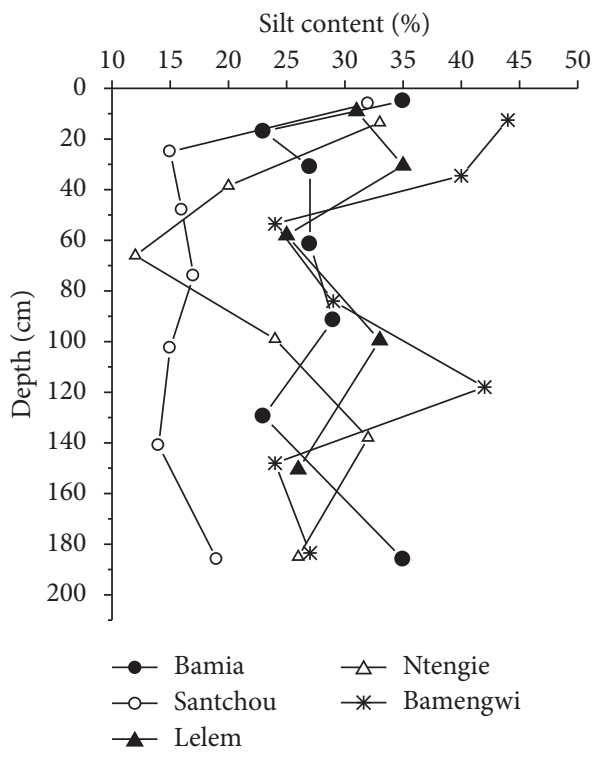

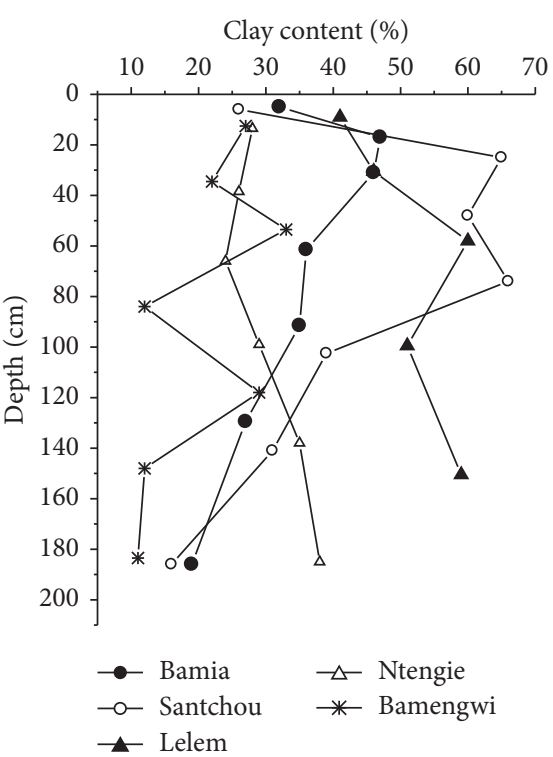

(b)

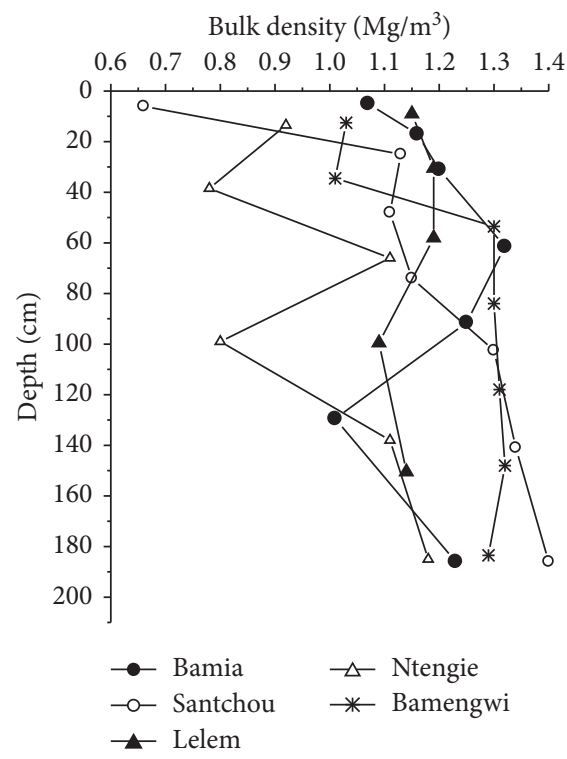

(d)

FIgURE 4: Continued. 


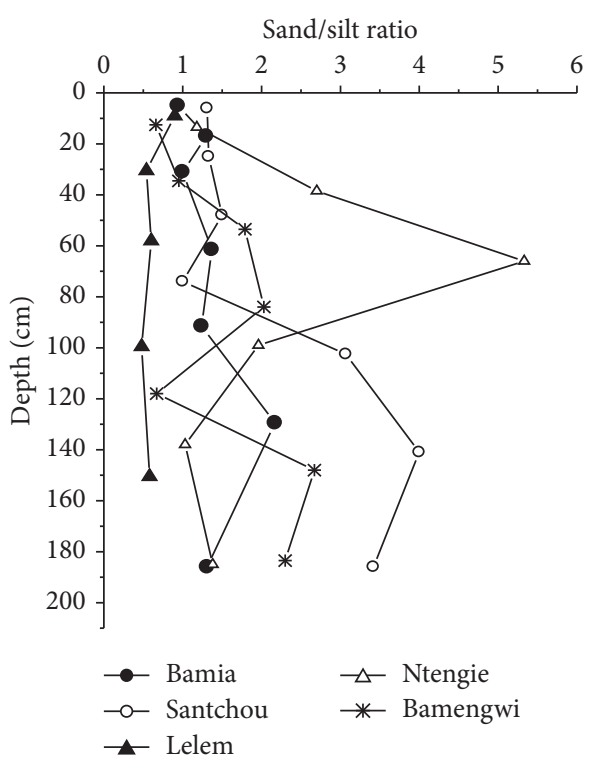

(e)

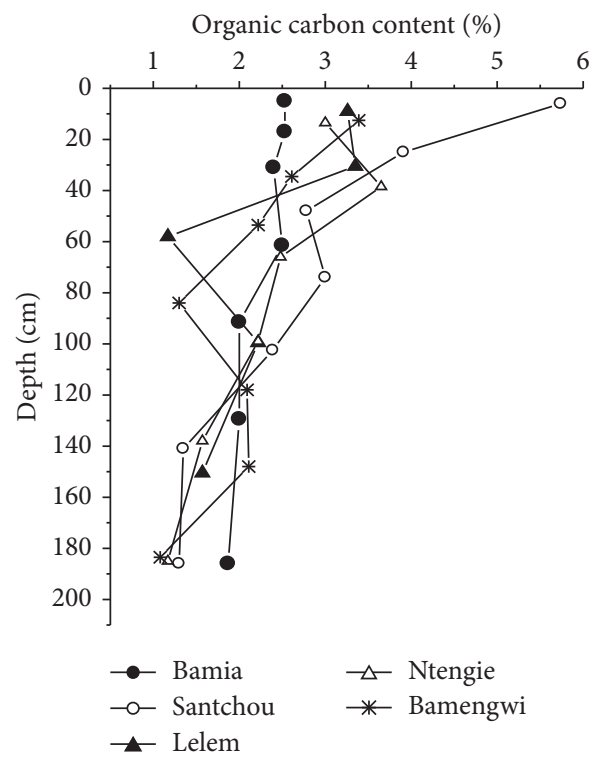

(g)

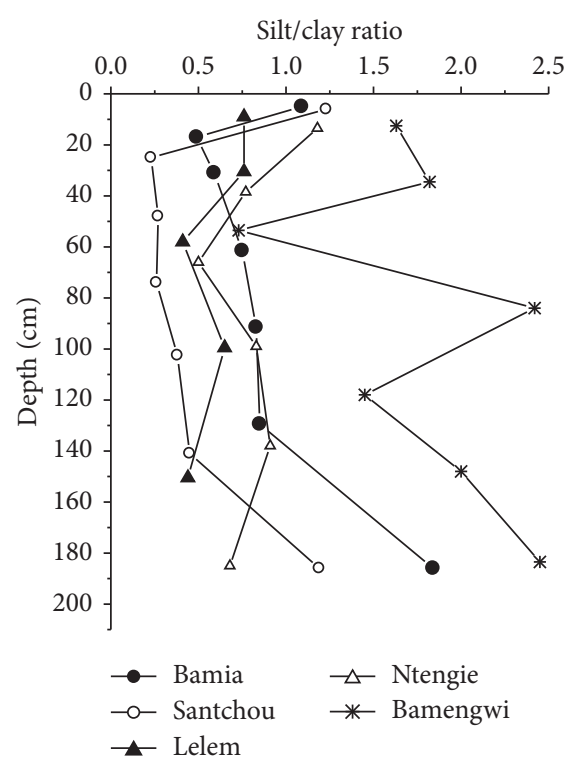

(f)

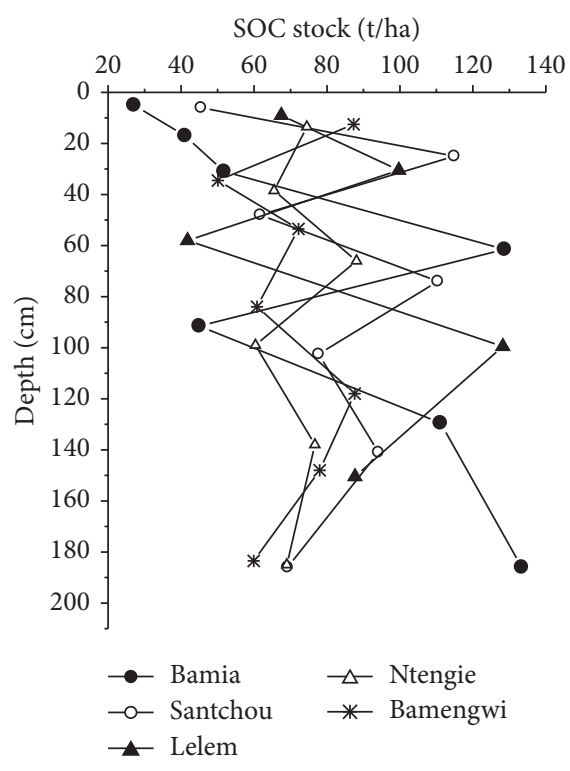

(h)

FIGURE 4: Variation of selected soil physical and chemical properties with depth.

3.3.2. Soil Organic Carbon Distribution. Soil organic carbon contents were generally higher in surface horizons and decreased with depth (Table 5, Figure 4). The surface Ah horizon of profile 2 has the highest SOC content of $5.74 \%$ contributed by the prevailing grassland vegetation. Generally, OM accumulation in the Ah horizon is largely dependent on the influx of litter-layer decomposition products and in situ accumulation of root decomposition products [69]. All the profiles recorded the lowest SOC contents in the $\mathrm{C}$ horizons, except for the $\mathrm{Bt}_{2}$ horizon of profile 3 . Despite the dominance of clay and clay loam textures in the surface horizons, SOC did not show any significant relationship with texture. The variation of SOC stocks with depth is consistent with the stratifications observed with depth in the soils derived from alluvium as corroborated by BD, sand, and sand/silt depth functions. The SOC stocks at a depth of $1 \mathrm{~m}$ were highest in profile 2 (under grassland vegetation) with an estimated value of $363.5 \mathrm{t} \cdot \mathrm{ha}^{-1}$, while the lowest values were recorded in profile 4 (farmland) $\left(260.1 \mathrm{t} \cdot \mathrm{ha}^{-1}\right.$ ) and profile $5\left(264.0 \mathrm{t} \cdot \mathrm{ha}^{-1}\right)$. Both soils with very high porosities and high sand contents would favor faster mineralization of OM, compared to the more rich clay soils [70], though increased tillage activities play a complementary role. Reports indicate that grassland soils store significant amounts of SOC and about $34 \%$ of the global terrestrial carbon [28]. 
TABLE 4: Physical properties of the soils.

\begin{tabular}{|c|c|c|c|c|c|c|c|c|c|c|c|}
\hline Horizon & Depth $(\mathrm{cm})$ & $\begin{array}{c}\mathrm{BD} \\
\left(\mathrm{Mg} \mathrm{m}^{-3}\right)\end{array}$ & $\begin{array}{c}\text { Porosity } \\
(\%)\end{array}$ & $\begin{array}{c}\text { WHC } \\
(\%)\end{array}$ & $\begin{array}{l}\text { Sand } \\
(\%)\end{array}$ & $\begin{array}{l}\text { Silt } \\
(\%) \\
\end{array}$ & $\begin{array}{l}\text { Clay } \\
(\%)\end{array}$ & $\begin{array}{l}\text { Clay } \\
\text { ratio }\end{array}$ & $\begin{array}{l}\text { Sand/silt } \\
\text { ratio }\end{array}$ & $\begin{array}{c}\text { Silt/clay } \\
\text { ratio }\end{array}$ & $\begin{array}{c}\text { Textural } \\
\text { class }^{*}\end{array}$ \\
\hline \multicolumn{12}{|c|}{ Profile 1. Bamia series } \\
\hline Ap & $0-10$ & 1.07 & 59.62 & 40.22 & 33 & 35 & 32 & 0.47 & 0.94 & 1.09 & $\mathrm{CL}$ \\
\hline $\mathrm{AB}$ & $10-24$ & 1.16 & 56.23 & 40.07 & 30 & 23 & 47 & 0.89 & 1.30 & 0.49 & $\mathrm{C}$ \\
\hline Bw1 & $24-42$ & 1.20 & 54.72 & 40.40 & 27 & 27 & 46 & 0.85 & 1.00 & 0.59 & $\mathrm{C}$ \\
\hline Bw2 & $42-72 / 90$ & 1.32 & 50.19 & 30.74 & 37 & 27 & 36 & 0.56 & 1.37 & 0.75 & $\mathrm{CL}$ \\
\hline Bw3 & $72 / 90-102$ & 1.25 & 52.83 & 30.46 & 36 & 29 & 35 & 0.54 & 1.24 & 0.83 & $\mathrm{CL}$ \\
\hline Cr1 & $102-157$ & 1.01 & 61.89 & 30.97 & 50 & 23 & 27 & 0.37 & 2.17 & 0.85 & SCL \\
\hline $\mathrm{Cr} 2$ & $157-215$ & 1.23 & 53.58 & 30.54 & 46 & 35 & 19 & 0.23 & 1.31 & 1.84 & $\mathrm{~L}$ \\
\hline \multicolumn{12}{|c|}{ Profile 2. Santchou series } \\
\hline $\mathrm{Ah}$ & $0-12$ & 0.66 & 75.09 & 49.02 & 42 & 32 & 26 & 0.35 & 1.31 & 1.23 & $\mathrm{~L}$ \\
\hline $2 \mathrm{Bt} / \mathrm{E}$ & $12-38$ & 1.13 & 57.34 & 31.85 & 20 & 15 & 65 & 1.86 & 1.33 & 0.23 & $\mathrm{HC}$ \\
\hline $2 \mathrm{E} / \mathrm{Bt}$ & $38-58$ & 1.11 & 58.11 & 32.21 & 24 & 16 & 60 & 1.50 & 1.50 & 0.27 & $\mathrm{C}$ \\
\hline 2Btg2 & $58-90$ & 1.15 & 56.60 & 34.90 & 17 & 17 & 66 & 1.94 & 1.00 & 0.26 & $\mathrm{HC}$ \\
\hline $2 \mathrm{Btg} 3$ & $90-115$ & 1.30 & 50.94 & 36.55 & 46 & 15 & 39 & 0.64 & 3.07 & 0.38 & $\mathrm{SC}$ \\
\hline $2 \mathrm{Cl}$ & $115-167$ & 1.34 & 49.43 & 33.48 & 56 & 14 & 31 & 0.44 & 4.00 & 0.45 & SCL \\
\hline $2 \mathrm{C} 2$ & 167-205 & 1.40 & 47.17 & 28.02 & 65 & 19 & 16 & 0.19 & 3.42 & 1.19 & SL \\
\hline \multicolumn{12}{|c|}{ Profile 3. Lelem series } \\
\hline A & $0-18$ & 1.15 & 56.60 & 31.75 & 28 & 31 & 41 & 0.69 & 0.90 & 0.76 & $\mathrm{C}$ \\
\hline Bt1 & $18-43$ & 1.19 & 55.09 & 35.15 & 19 & 35 & 46 & 0.86 & 0.54 & 0.76 & $\mathrm{C}$ \\
\hline Bt2 & $43-73$ & 1.19 & 55.09 & 31.22 & 15 & 25 & 60 & 1.50 & 0.60 & 0.41 & $\mathrm{C}$ \\
\hline Btg & $73-118 / 134$ & 1.09 & 58.87 & 31.40 & 16 & 33 & 51 & 1.04 & 0.48 & 0.65 & $\mathrm{C}$ \\
\hline BCtg & $118 / 134-175$ & 1.14 & 56.98 & 29.98 & 15 & 26 & 59 & 1.44 & 0.58 & 0.44 & $\mathrm{C}$ \\
\hline \multicolumn{12}{|c|}{ Profile 4. Ntengie series } \\
\hline Ap & $0-27$ & 0.92 & 65.28 & 35.68 & 39 & 33 & 28 & 0.39 & 1.18 & 1.18 & $\mathrm{CL}$ \\
\hline $\mathrm{AB}$ & $27-50$ & 0.78 & 70.57 & 42.64 & 54 & 20 & 26 & 0.35 & 2.70 & 0.77 & SCL \\
\hline $\mathrm{Cg}$ & $50-82$ & 1.11 & 58.11 & 35.05 & 64 & 12 & 24 & 0.32 & 5.33 & 0.50 & SCL \\
\hline $2 \mathrm{AB}$ & $82-116$ & 0.80 & 69.81 & 38.88 & 47 & 24 & 29 & 0.41 & 1.96 & 0.83 & SCL \\
\hline $2 \mathrm{Btg}$ & $116-160$ & 1.11 & 58.11 & 27.12 & 33 & 32 & 35 & 0.54 & 1.03 & 0.91 & $\mathrm{CL}$ \\
\hline $2 \mathrm{BC}$ & $160-210$ & 1.18 & 55.47 & 36.34 & 36 & 26 & 38 & 0.61 & 1.38 & 0.68 & $\mathrm{CL}$ \\
\hline \multicolumn{12}{|c|}{ Profile 5. Bamengwi series } \\
\hline Ap & $0-25$ & 1.03 & 61.13 & 35.01 & 29 & 44 & 27 & 0.37 & 0.66 & 1.63 & CL \\
\hline $\mathrm{AB}$ & $25-44$ & 1.01 & 61.89 & 37.61 & 38 & 40 & 22 & 0.28 & 0.95 & 1.82 & $\mathrm{~L}$ \\
\hline $\mathrm{BCt}$ & $41-66$ & 1.30 & 50.94 & 28.06 & 43 & 24 & 33 & 0.49 & 1.79 & 0.73 & CL \\
\hline $2 \mathrm{Cg} 1$ & $66-102$ & 1.30 & 50.94 & 32.82 & 59 & 29 & 12 & 0.14 & 2.03 & 2.42 & SL \\
\hline $3 \mathrm{Cg} 2$ & $102-134$ & 1.31 & 50.57 & 33.08 & 28 & 42 & 29 & 0.41 & 0.67 & 1.45 & CL \\
\hline $4 \mathrm{Cg} 3$ & $134-162$ & 1.32 & 50.19 & 33.74 & 64 & 24 & 12 & 0.14 & 2.67 & 2.00 & SL \\
\hline $5 \mathrm{Cg} 4$ & $162-205$ & 1.29 & 51.32 & 35.16 & 62 & 27 & 11 & 0.12 & 2.30 & 2.45 & SL \\
\hline
\end{tabular}

*Textural class according to FAO [60]. WHC water holding capacity, CL clay loam, C clay, SCL sandy clay loam, L loam, HC heavy clay, SC sandy clay, and SL sandy loam.

3.3.3. Relationship between SOC and Physicochemical Properties. Correlation analysis indicates that SOC and SOC stocks have significant relationships with some physical and chemical soil properties (Table 6, Figure 5). A negative and significant correlation exists between $\mathrm{SOC}$ and $\mathrm{BD}$ $(r=-0.648 p<0.01)$, reflecting the classical relationship that exists between them and further confirming that BD across the soil profiles is largely influenced by OM content. The positive and significant relationship between SOC and water holding capacity (WHC) $(r=0.589, p<0.01)$ indicates that increase in SOM increases the soil's ability to retain water. However, there was a negative and significant relationship between SOC stocks and WHC $(r=-0.451, p<0.01)$ and also a negative and significant relationship between $\mathrm{BD}$ and WHC $(r=-0.636, p<0.01)$. A multiple linear regression equation between WHC as the dependent variable with SOC and $\mathrm{BD}$ as independent variables was established as follows: $\mathrm{WHC}=44.51+1.47 \times \mathrm{SOC}-11.96 \times \mathrm{BD} \quad\left(R^{2}=0.460, \quad p<\right.$ 0.05). This indicates that SOC and BD can explain $46 \%$ of the variance associated with $\mathrm{WHC}$, and thus this equation could be used to estimate WHC from SOC and BD data. Soil organic carbon had a positive and significant correlation with exchangeable $\mathrm{Al}^{3+}(r=0.707, \quad p<0.01)$ and exchangeable $\mathrm{H}^{+}(r=0.456, p<0.05)$ when the data were pooled together. The relationship between SOC and exchangeable acidity would only be valid for profiles 2,3 , and 4 with $\mathrm{pH}-\mathrm{H}_{2} \mathrm{O}$ values $<5.5$. However, the relationship between SOC and exchangeable $\mathrm{Al}^{3+}$ was strongest in profile 2 $(r=0.931, p<0.01)$. A linear regression between SOC and exchangeable $\mathrm{Al}^{3+}$ in profile 2 gave an $R^{2}$ value of 0.867 (Figure 6), indicating that SOC can be conveniently estimated from exchangeable $\mathrm{Al}^{3+}$ in this soil type. The 
TABLE 5: Chemical properties and SOC stocks.

\begin{tabular}{|c|c|c|c|c|c|c|c|c|c|c|}
\hline Horizon & $\begin{array}{l}\text { Depth } \\
(\mathrm{cm})\end{array}$ & $\begin{array}{l}\mathrm{pH}- \\
\mathrm{H}_{2} \mathrm{O}\end{array}$ & $\begin{array}{c}\mathrm{pH}- \\
\mathrm{CaCl}_{2}\end{array}$ & $\begin{array}{l}\mathrm{pH}- \\
\mathrm{KCl}\end{array}$ & $\begin{array}{c}\mathrm{EC} \\
\left(\mathrm{dSm}^{-1}\right)\end{array}$ & $\begin{array}{c}\text { SOC } \\
(\%)\end{array}$ & $\begin{array}{l}\text { SOC stocks } \\
\left(\mathrm{t} \mathrm{ha}^{-1}\right)\end{array}$ & $\begin{array}{c}\text { SOC stocks at } 100 \mathrm{~cm} \\
\text { depth }\left(\mathrm{t} \mathrm{ha}^{-1}\right)\end{array}$ & $\begin{array}{c}\mathrm{Al}^{3+} \\
\left(\mathrm{cmol}_{\mathrm{c}} \mathrm{kg}^{-1}\right)\end{array}$ & $\begin{array}{c}\mathrm{H}^{+} \\
\left(\mathrm{cmol}_{\mathrm{c}} \mathrm{kg}^{-1}\right)\end{array}$ \\
\hline \multicolumn{11}{|c|}{ Profile 1. Bamia series } \\
\hline Ap & $0-10$ & 5.8 & 5.1 & 4.5 & 0.03 & 2.53 & 27.1 & \multirow{7}{*}{295.7} & - & - \\
\hline $\mathrm{AB}$ & $10-24$ & 5.6 & 4.8 & 4.2 & 0.01 & 2.53 & 41.1 & & - & - \\
\hline $\mathrm{Bw}_{1}$ & 24-42 & 5.5 & 4.4 & 4.0 & 0.01 & 2.40 & 51.8 & & - & - \\
\hline $\mathrm{Bw}_{2}$ & $42-72 / 90$ & 5.4 & 4.4 & 4.0 & 0.01 & 2.50 & 128.7 & & 0.9 & 0.0 \\
\hline $\mathrm{Bw}_{3}$ & $72 / 90-102$ & 5.5 & 4.6 & 4.1 & 0.01 & 2.0 & 45.0 & & - & - \\
\hline $\mathrm{Cr}_{1}$ & $102-157$ & 5.6 & 4.5 & 4.1 & 0.01 & 2.0 & 111.1 & & - & - \\
\hline $\mathrm{Cr}_{2}$ & $157-215$ & 5.6 & 4.5 & 4.2 & 0.01 & 1.87 & 133.4 & & - & - \\
\hline \multicolumn{11}{|c|}{ Profile 2. Santchou series } \\
\hline $\mathrm{Ah}$ & $0-12$ & 4.8 & 4.3 & 3.8 & 0.02 & 5.74 & 45.5 & \multirow{7}{*}{363.5} & 3.3 & 2.2 \\
\hline $2 \mathrm{Bt} / \mathrm{E}$ & $12-38$ & 4.8 & 4.5 & 4.1 & 0.01 & 3.91 & 114.9 & & 1.8 & 2.3 \\
\hline $2 \mathrm{E} / \mathrm{Bt}$ & $38-58$ & 4.5 & 4.1 & 3.6 & 0.01 & 2.78 & 61.7 & & 0.5 & 2.0 \\
\hline 2Btg2 & $58-90$ & 4.5 & 4.0 & 3.8 & 0.01 & 3.00 & 110.4 & & 1.7 & 1.4 \\
\hline $2 \mathrm{Btg} 3$ & $90-115$ & 5.0 & 4.8 & 4.4 & 0.01 & 2.39 & 77.7 & & 0.8 & 0.7 \\
\hline $2 \mathrm{C} 1$ & $115-167$ & 4.7 & 4.2 & 4.0 & 0.00 & 1.35 & 94.1 & & 0.6 & 0.5 \\
\hline $2 \mathrm{C} 2$ & $167-205$ & 4.9 & 4.5 & 4.2 & 0.00 & 1.30 & 69.2 & & 0.5 & 0.0 \\
\hline \multicolumn{11}{|c|}{ Profile 3. Lelem series } \\
\hline A & $0-18$ & 4.5 & 4.0 & 3.5 & 0.01 & 3.26 & 67.5 & \multirow{5}{*}{274.2} & 0.7 & 1.6 \\
\hline Bt1 & $18-43$ & 4.7 & 4.1 & 3.6 & 0.01 & 3.35 & 99.7 & & 0.5 & 1.5 \\
\hline Bt2 & $43-73$ & 4.8 & 4.3 & 3.5 & 0.00 & 1.17 & 41.8 & & 0.6 & 1.9 \\
\hline Btg & $\begin{array}{c}73-118 / \\
134\end{array}$ & 4.8 & 4.4 & 3.6 & 0.00 & 2.22 & 128.2 & & 0.7 & 1.4 \\
\hline BCtg & $\begin{array}{c}118 / \\
134-175\end{array}$ & 4.9 & 4.3 & 3.8 & 0.01 & 1.57 & 87.7 & & 0.4 & 1.3 \\
\hline \multicolumn{11}{|c|}{ Profile 4. Ntengie series } \\
\hline Ap & $0-27$ & 5.3 & 5.0 & 4.3 & 0.04 & 3.00 & 74.5 & \multirow{6}{*}{260.1} & 0.2 & 0.0 \\
\hline $\mathrm{AB}$ & $27-50$ & 5.2 & 4.7 & 4.3 & 0.02 & 3.65 & 65.5 & & 0.2 & 0.0 \\
\hline $\mathrm{Cg}$ & $50-82$ & 5.2 & 4.8 & 4.3 & 0.02 & 2.48 & 88.1 & & 0.2 & 0.0 \\
\hline $2 \mathrm{AB}$ & $82-116$ & 5.4 & 5.0 & 4.8 & 0.02 & 2.22 & 60.4 & & 0.3 & 0.0 \\
\hline $2 \mathrm{Btg}$ & $116-160$ & 5.5 & 5.1 & 4.6 & 0.02 & 1.57 & 76.7 & & 0.3 & 0.0 \\
\hline $2 \mathrm{BC}$ & $160-210$ & 5.5 & 4.9 & 4.4 & 0.02 & 1.17 & 69.0 & & 0.3 & 0.0 \\
\hline \multicolumn{11}{|c|}{ Profile 5. Bamengwi series } \\
\hline Ap & $0-25$ & 5.7 & 5.1 & 4.2 & 0.02 & 3.39 & 87.3 & \multirow{7}{*}{264.0} & - & - \\
\hline $\mathrm{AB}$ & $25-44$ & 6.0 & 5.6 & 4.6 & 0.01 & 2.61 & 50.1 & & - & - \\
\hline $\mathrm{BCt}$ & $41-66$ & 6.0 & 5.3 & 4.5 & 0.01 & 2.22 & 72.2 & & - & - \\
\hline $2 \mathrm{Cg} 1$ & $66-102$ & 6.2 & 5.8 & 4.7 & 0.01 & 1.30 & 60.8 & & - & - \\
\hline $3 \mathrm{Cg} 2$ & $102-134$ & 6.1 & 5.6 & 4.9 & 0.01 & 2.09 & 87.6 & & - & - \\
\hline $4 \mathrm{Cg} 3$ & $134-162$ & 6.4 & 5.8 & 5.1 & 0.01 & 2.11 & 78.0 & & - & - \\
\hline $5 \mathrm{Cg} 4$ & $162-205$ & 6.2 & 5.8 & 4.9 & 0.01 & 1.08 & 59.9 & & - & - \\
\hline
\end{tabular}

relationship shows that exchangeable $\mathrm{Al}^{3+}$ forms strong complexes with $\mathrm{OM}$ as best observed in the humic surface horizon of profile 2 . Low $\mathrm{pH}$ soils such as those in this study are reported to have $\mathrm{Al}^{3+}-\mathrm{OM}$ complexation as well as $\mathrm{Al}^{3+}$ toxicity as the main OM stabilization mechanisms [20, 71]. In view of the role played by soil $\mathrm{pH}$ in controlling soil OM stabilization mechanisms, Clarholm and Skyllberg [20] indicate that soil $\mathrm{pH}$ values between 6.2 and 6.8 constitute a "window of opportunity," whereby SOM stabilization controlled by cations such as $\mathrm{Al}$ is not strong. Variations in soil $\mathrm{pH}$ in these soils would thus be attributed to both SOM type and clay content, given that a positive correlation exists between clay content and exchangeable $\mathrm{H}^{+} \quad(r=0.708$, $p<0.01)$. The positive relationship observed between OC and exchangeable $\mathrm{H}^{+}$indicates that soil acidity increases with increase in SOM content. Given that $\mathrm{H}^{+}$is part of the humus carboxyl $(-\mathrm{COOH})$ under acidic conditions, when the soil's acidity decreases, there is a greater tendency for the $\mathrm{H}^{+}$to be removed from humic acids and to react with hydroxyl $\left(\mathrm{OH}^{-}\right)$to form water. The carboxyl groups on the humus develop negative charges as the positively charged $\mathrm{H}^{+}$ is removed. When the soil $\mathrm{pH}$ is increased, the release of $\mathrm{H}$ from carboxyl groups helps to buffer the increase in $\mathrm{pH}$ and at the same time creates the CEC (negative charge). Thus, when OM increases, the soil recovers its natural buffer capacity, thereby increasing soil $\mathrm{pH}$ and hence increasing the soil's capacity to retain cations.

In general, there was no significant relationship between SOC and texture. Observations by Hassink [16] indicate that SOC contents varied considerably between soils with similar clay and silt contents. However, the latter found highly significant positive correlations between the clay and silt 


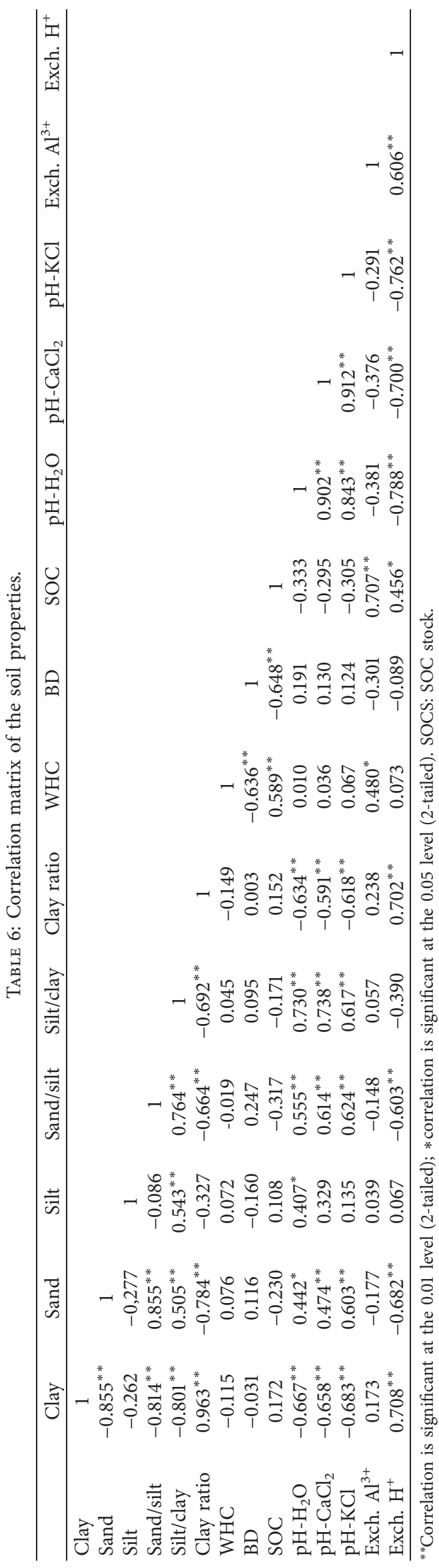




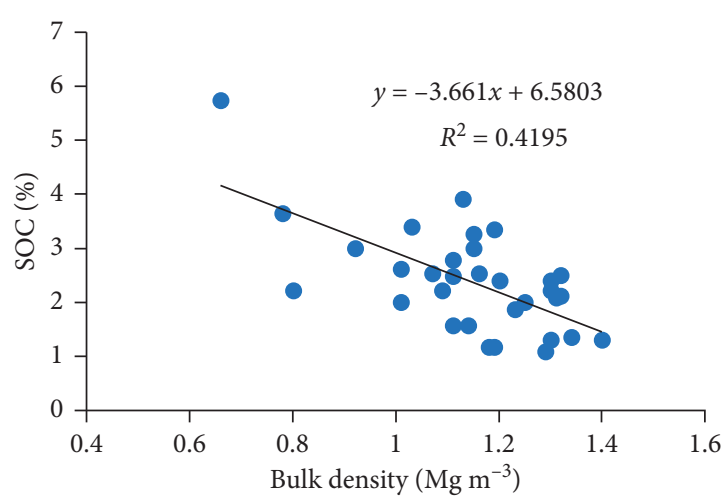

(a)

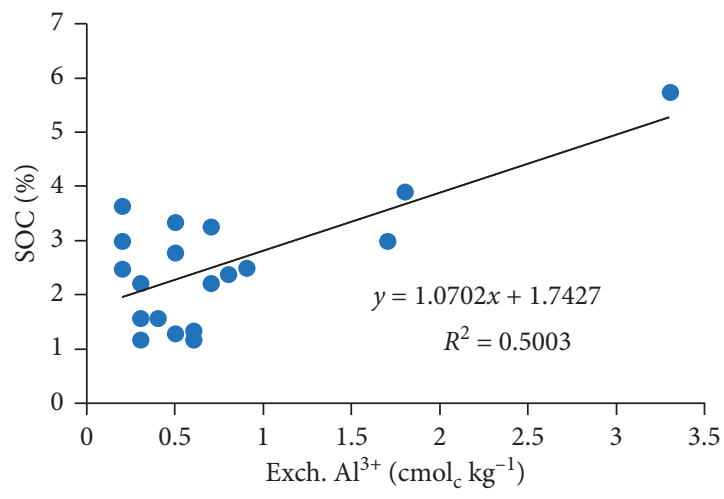

(c)

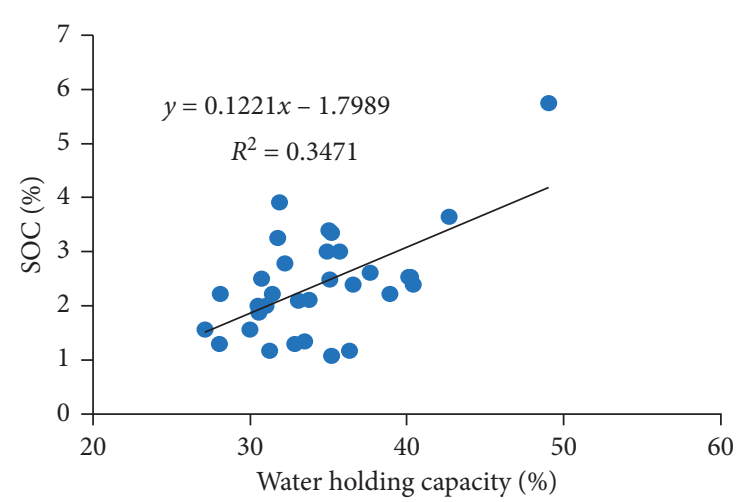

(b)

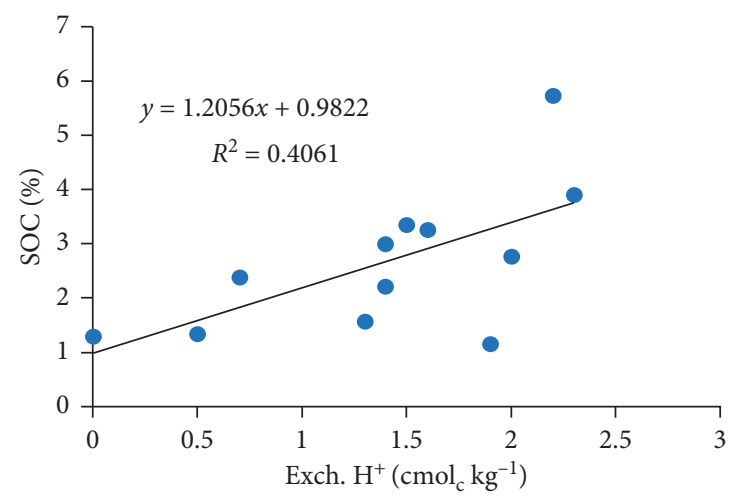

(d)

FIGURE 5: Relationships between SOC content and selected soil properties.

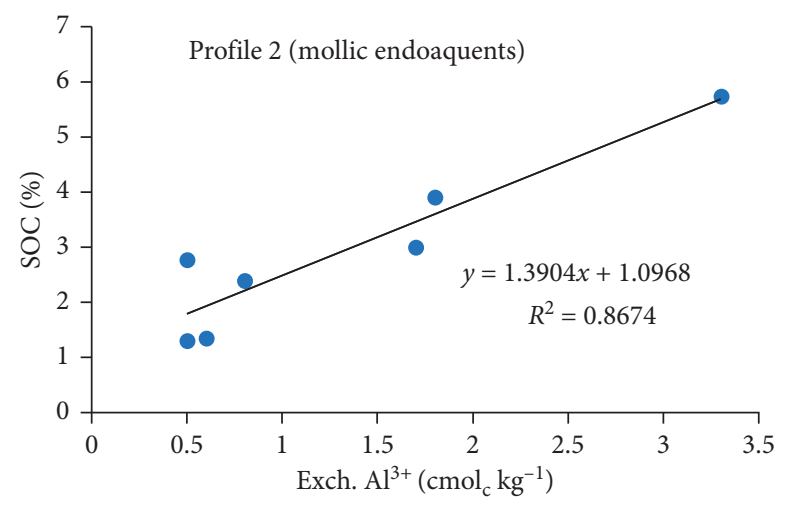

FIGURE 6: Relationship between SOC and exchangeable $\mathrm{Al}^{3+}$ in profile 2 (Mollic Endoaquents).

contents of some soils and the amounts of $\mathrm{C}$ associated with these fractions; in some cases, lower amounts of $\mathrm{C}$ were associated with the fine-sized particles. These observations indicate that the amount of SOC that can be bound or adsorbed is a function of the type of clay minerals present (phyllosilicates versus sesquioxides) and their corresponding specific surface area and charge characteristics which impact on this behaviour [32]. With the diversity of soil types observed in this study, having a wide range of silt/clay ratios, apparently these soils exhibit wide mineralogical differences with corresponding differences in their binding capacity with SOC. Thus, other factors, apart from soil texture, such as land use type and management ( $\mathrm{C}$ additions) would likely be responsible for SOC storage [72, 73].

3.3.4. Relationship between SOC and Soil Color. Soil organic carbon contents had a negative correlation with soil value and/or soil chroma in both moist and dry states (Table 7). These results indicate that, based on the correlation coefficients, Munsell soil color attributes explain between 40 and $57 \%$ of the variance associated with SOM. This has important implications for application as Zelenak [74] reported that soil color could successfully be used to estimate SOM 
TABLE 7: Correlation matrix between SOC and Munsell color attributes.

\begin{tabular}{|c|c|c|c|c|c|c|c|}
\hline & VM & $\mathrm{CM}$ & $\mathrm{VM}+\mathrm{CM}$ & VD & $\mathrm{CD}$ & $\mathrm{VD}+\mathrm{CD}$ & SOC \\
\hline VM & 1 & & & & & & \\
\hline $\mathrm{CM}$ & 0.338 & 1 & & & & & \\
\hline $\mathrm{VM}+\mathrm{CM}$ & $0.670^{* *}$ & $0.925^{* *}$ & 1 & & & & \\
\hline VD & $0.659^{* *}$ & $0.425^{*}$ & $0.601^{* *}$ & 1 & & & \\
\hline $\mathrm{CD}$ & -0.125 & -0.052 & -0.091 & $-0.471^{* *}$ & 1 & & \\
\hline $\mathrm{VD}+\mathrm{CD}$ & $0.545^{* *}$ & $0.379^{*}$ & $0.519^{* *}$ & $0.564^{* *}$ & $0.463^{* *}$ & 1 & \\
\hline SOC & $-0.573^{* *}$ & $-0.402^{*}$ & $-0.549^{* *}$ & $-0.515^{* *}$ & -0.021 & $-0.537^{* *}$ & 1 \\
\hline
\end{tabular}

${ }^{* *}$ Correlation is significant at the 0.01 level (2-tailed); *correlation is significant at the 0.05 level (2-tailed). VM: value (moist), CM: chroma (moist), $\mathrm{VM}+\mathrm{CM}$ : value (moist) + chroma (moist), VD: value (dry), CD: chroma (dry), VD + CD: value (dry) + chroma (dry).

contents as it could explain approximately $50 \%$ of the variance associated with SOM. Pretorius et al. [75] reported that, based on a high coefficient of determination $\left(R^{2}=0.91\right)$ for coastal plain soils of South Africa, when the sum of dry and wet value and chroma values is 9 or more, carbon content will be $\leq 4.79 \%$. From the results of this study, soil color attributes, notably value and chroma, can be conveniently used to estimate organic matter contents, where cost constraints are an important factor in laboratory analyses.

\section{Conclusion}

In this study, SOC contents and stocks in five major soils types of the Mbo plain were estimated, and SOC distribution along soil profiles presents erratic depth functions. SOC had significant correlations with exchangeable $\mathrm{Al}^{3+}$ and $\mathrm{H}^{+}$, bulk density, water holding capacity, and Munsell soil color attributes. The correlations indicate that soil SOC can be conveniently estimated from exchangeable $\mathrm{Al}^{3+}$ in the Mollic Endoaquents. The results obtained in this study serve as baseline information that can be used for monitoring soil quality changes in this humid tropical environment, especially in areas subjected to intensive agricultural practices. Future studies to investigate detailed biological, chemical, and mineralogical properties are recommended in order to acquire more knowledge on soils of the Mbo plain. Additionally, detailed studies on the spatial variability of SOC are recommended in order to guide decision-making on sustainable soil management in the plain.

\section{Data Availability}

The data used in this paper are available from the corresponding author upon request.

\section{Conflicts of Interest}

The authors declare no conflicts of interest.

\section{References}

[1] A. E. Hartemink, R. Lal, M. H. Gerzabek et al., "Soil carbon research and global environmental challenges," PeerJ PrePrints, vol. 2, Article ID e366v1, 2014.

[2] K. Adhikari and A. E. Hartemink, "Linking soils to ecosystem services-a global review," Geoderma, vol. 262, pp. 101-111, 2016.
[3] N. H. Batjes, "Total carbon and nitrogen in the soils of the world," European Journal of Soil Science, vol. 47, no. 2, pp. 151-163, 1996.

[4] W. H. Schlesinger, "Carbon balance in terrestrial detritus," Annual Review of Ecology and Systematics, vol. 8, no. 1, pp. 51-81, 1977.

[5] R. Lal, "Managing soils and ecosystems for mitigating anthropogenic carbon emissions and advancing global food security," BioScience, vol. 60, no. 9, pp. 708-721, 2010.

[6] L. Ouyang, L. Yu, and R. Zhang, "Effects of amendment of different biochars on soil carbon mineralisation and sequestration," Soil Research, vol. 52, no. 1, pp. 46-54, 2014.

[7] X. Han, C. Xu, J. A. J. Dungait et al., "Straw incorporation increases crop yield and soil organic carbon sequestration but varies under different natural conditions and farming practices in China: a system analysis," Biogeosciences, vol. 15, no. 7, pp. 1933-1946, 2018.

[8] D. Han, M. Wiesmeier, R. T. Conant et al., "Large soil organic carbon increase due to improved agronomic management in the North China Plain from 1980s to 2010s," Global Change Biology, vol. 24, no. 3, pp. 987-1000, 2018.

[9] K. R. Olson, S. A. Ebelhar, and J. M. Lang, "Effects of 24 years of conservation tillage systems on soil organic carbon and soil productivity," Applied and Environmental Soil Science, vol. 2013, Article ID 617504, , 2013.

[10] R. Moussadek, R. Mrabet, R. Dahan, A. Zouahri, M. El Mourid, and E. Van Ranst, "Tillage system affects soil organic carbon storage and quality in Central Morocco," Applied and Environmental Soil Science, vol. 2014, Article ID 654796, , 2014.

[11] P. Omara, L. Aula, E. M. Eickhoff et al., "Influence of Notillage on soil organic carbon, total soil nitrogen, and winter wheat (Triticum aestivum L.) grain yield," International Journal of Agronomy, vol. 2019, Article ID 9632969, , 2019.

[12] S. I. C. Akpa, I. O. A. Odeh, T. F. A. Bishop, A. E. Hartemink, and I. Y. Amapu, "Total soil organic carbon and carbon sequestration potential in Nigeria," Geoderma, vol. 271, pp. 202-215, 2016.

[13] Y. Gao, J. Zhou, L. Wang et al., "Distribution patterns and controlling factors for the soil organic carbon in four mangrove forests of China," Global Ecology and Conservation, vol. 17, Article ID e00575, 2019.

[14] Y. Yang, D. Tilman, G. Furey, and C. Lehman, "Soil carbon sequestration accelerated by restoration of grassland biodiversity," Nature Communications, vol. 10, no. 1, p. 718, 2019.

[15] P. Laban, G. Metternicht, and J. Davies, Soil Biodiversity and Soil Organic Carbon: Keeping Drylands Alive, Gland, Switzerland, 2018.

[16] J. Hassink, "The capacity of soils to preserve organic C and N by their association with clay and silt particles," Plant and Soil, vol. 191, no. 1, pp. 77-87, 1997. 
[17] B. A. Willaarts, C. Oyonarte, M. Muñoz-Rojas, J. J. Ibáñez, and P. A. Aguilera, "Environmental factors controlling soil organic carbon stocks in two contrasting Mediterranean climatic areas of southern Spain," Land Degradation \& Development, vol. 27, no. 3, pp. 603-611, 2016.

[18] D. R. P. Gonçalves, J. C. d. M. Sá, U. Mishra, C. E. P. Cerri, L. A. Ferreira, and F. J. F. Furlan, "Soil type and texture impacts on soil organic carbon storage in a sub-tropical agroecosystem," Geoderma, vol. 286, pp. 88-97, 2017.

[19] E. Tipping and C. Woof, "Humic substances in acid organic soils: modelling their release to the soil solution in terms of humic charge," Journal of Soil Science, vol. 41, no. 4, pp. 573-586, 1990.

[20] M. Clarholm and U. Skyllberg, "Translocation of metals by trees and fungi regulates $\mathrm{pH}$, soil organic matter turnover and nitrogen availability in acidic forest soils," Soil Biology and Biochemistry, vol. 63, pp. 142-153, 2013.

[21] S. Yang, B. Jansen, K. Kalbitz, F. O. C. Castro, R. L. van Hall, and E. L. Cammeraat, "Lithology controlled soil organic carbon stabilization in an alpine grassland of the Peruvian Andes," Environmental Earth Sciences, vol. 79, no. 2, p. 66, 2020.

[22] J. Six, P. Callewaert, S. Lenders et al., "Measuring and understanding carbon storage in afforested soils by physical fractionation," Soil Science Society of America Journal, vol. 66, no. 6, pp. 1981-1987, 2002.

[23] G. J. Churchman, "Game Changer in Soil Science. Functional role of clay minerals in soil," Journal of Plant Nutrition and Soil Science, vol. 181, no. 1, pp. 99-103, 2018.

[24] K. U. Totsche, W. Amelung, M. H. Gerzabek et al., "Microaggregates in soils," Journal of Plant Nutrition and Soil Science, vol. 181, no. 1, pp. 104-136, 2018.

[25] E. A. Davidson and I. A. Janssens, "Temperature sensitivity of soil carbon decomposition and feedbacks to climate change," Nature, vol. 440, no. 7081, p. 165, 2006.

[26] E. G. Jobbágy and R. B. Jackson, "The vertical distribution of soil organic carbon and its relation to climate and vegetation," Ecological Applications, vol. 10, no. 2, pp. 423-436, 2000.

[27] M. Wiesmeier, M. V. Lützow, P. Spörlein et al., "Land use effects on organic carbon storage in soils of Bavaria: the importance of soil types," Soil and Tillage Research, vol. 146, pp. 296-302, 2015.

[28] S. Eze, S. M. Palmer, and P. J. Chapman, "Soil organic carbon stock in grasslands: effects of inorganic fertilizers, liming and grazing in different climate settings," Journal of Environmental Management, vol. 223, pp. 74-84, 2018.

[29] N. Mehta, N. R. Pandya, V. O. Thomas, and N. S. R. Krishnayya, "Impact of rainfall gradient on aboveground biomass and soil organic carbon dynamics of forest covers in Gujarat, India," Ecological Research, vol. 29, no. 6, pp. 1053-1063, 2014.

[30] K. Van Oost, T. A. Quine, G. Govers et al., "The impact of agricultural soil erosion on the global carbon cycle," Science, vol. 318, no. 5850, pp. 626-629, 2007.

[31] G. Gelybó, E. Tóth, C. Farkas, Á. Horel, I. Kása, and Z. Bakacsi, "Potential impacts of climate change on soil properties," Agrokémia És Talajtan, vol. 67, no. 1, pp. 121-141, 2018.

[32] Y. L. Zinn, R. Lal, J. M. Bigham, and D. V. S. Resck, "Edaphic controls on soil organic carbon retention in the Brazilian Cerrado: texture and mineralogy," Soil Science Society of America Journal, vol. 71, no. 4, pp. 1204-1214, 2007.

[33] F. Rakhsh, A. Golchin, A. Beheshti Al Agha, and P. Alamdari, "Effects of exchangeable cations, mineralogy and clay content on the mineralization of plant residue carbon," Geoderma, vol. 307, pp. 150-158, 2017.

[34] T. Chevallier, K. Fujisaki, O. Roupsard et al., "Short-range-order minerals as powerful factors explaining deep soil organic carbon stock distribution: the case of a coffee agroforestry plantation on Andosols in Costa Rica," SOIL, vol. 5, no. 2, pp. 315-332, 2019.

[35] X. Xu, W. Zhang, M. Xu et al., "Characteristics of differently stabilised soil organic carbon fractions in relation to longterm fertilisation in Brown Earth of Northeast China," Science of the Total Environment, vol. 572, pp. 1101-1110, 2016.

[36] S. E. Trumbore, "Potential responses of soil organic carbon to global environmental change," Proceedings of the National Academy of Sciences, vol. 94, no. 16, pp. 8284-8291, 1997.

[37] M. Cheng, Y. Xiang, Z. Xue, S. An, and F. Darboux, "Soil aggregation and intra-aggregate carbon fractions in relation to vegetation succession on the Loess Plateau, China," Catena, vol. 124, pp. 77-84, 2015.

[38] K. Van Oost, G. Verstraeten, S. Doetterl et al., "Legacy of human-induced $\mathrm{C}$ erosion and burial on soil-atmosphere $\mathrm{C}$ exchange," Proceedings of the National Academy of Sciences, vol. 109, no. 47, pp. 19492-19497, 2012.

[39] K. R. Olson, M. Al-Kaisi, R. Lal, and L. Cihacek, "Impact of soil erosion on soil organic carbon stocks," Journal of Soil and Water Conservation, vol. 71, no. 3, pp. 61A-67A, 2016.

[40] C. Fissore, B. J. Dalzell, A. A. Berhe, M. Voegtle, M. Evans, and A. $\mathrm{Wu}$, "Influence of topography on soil organic carbon dynamics in a Southern California grassland," Catena, vol. 149, pp. 140-149, 2017.

[41] L. Parras-Alcántara, B. Lozano-García, and A. Galán-Espejo, "Soil organic carbon along an altitudinal gradient in the Despeñaperros Natural Park, southern Spain," Solid Earth, vol. 6, no. 1, pp. 125-134, 2015 a.

[42] Y. G. Dialynas, S. Bastola, R. L. Bras, S. A. Billings, D. Markewitz, and D. d. Richter, "Topographic variability and the influence of soil erosion on the carbon cycle," Global Biogeochemical Cycles, vol. 30, no. 5, pp. 644-660, 2016.

[43] E. Hobley, B. Wilson, A. Wilkie, J. Gray, and T. Koen, "Drivers of soil organic carbon storage and vertical distribution in Eastern Australia," Plant and Soil, vol. 390, no. 1-2, pp. 111-127, 2015.

[44] L. Parras-Alcántara, B. Lozano-García, E. C. Brevik, and A. Cerdá, "Soil organic carbon stocks assessment in Mediterranean natural areas: a comparison of entire soil profiles and soil control sections," Journal of Environmental Management, vol. 155, pp. 219-228, 2015b.

[45] J. A. González-Pérez, F. J. González-Vila, G. Almendros, and H. Knicker, "The effect of fire on soil organic matter-a review," Environment International, vol. 30, no. 6, pp. 855-870, 2004.

[46] H. Knicker, "How does fire affect the nature and stability of soil organic nitrogen and carbon? A review," Biogeochemistry, vol. 85, no. 1, pp. 91-118, 2007.

[47] A. F. A. Pellegrini, A. Ahlström, S. E. Hobbie et al., "Fire frequency drives decadal changes in soil carbon and nitrogen and ecosystem productivity," Nature, vol. 553, no. 7687, p. 194, 2018.

[48] D. S. Schimel, B. H. Braswell, E. A. Holland et al., "Climatic, edaphic, and biotic controls over storage and turnover of carbon in soils," Global Biogeochemical Cycles, vol. 8, no. 3, pp. 279-293, 1994.

[49] J. M. Melillo, D. W. Kicklighter, A. D. McGuire, W. T. Peterjohn, and K. M. Newkirk, "Global change and its effects on soil organic carbon stocks," in Role of Nonliving Organic Matter in the Earth's Carbon Cycle, R. G. Zepp and 
C. Sonntag, Eds., pp. 175-189, John Wiley and Sons, Hoboken, NJ, USA, 1995.

[50] C. Rumpel and I. Kögel-Knabner, "Deep soil organic matter-a key but poorly understood component of terrestrial C cycle," Plant and Soil, vol. 338, no. 1-2, pp. 143-158, 2011.

[51] K. Adhikari, P. R. Owens, Z. Libohova, D. M. Miller, S. A. Wills, and J. Nemecek, "Assessing soil organic carbon stock of Wisconsin, USA and its fate under future land use and climate change," Science of the Total Environment, vol. 667, pp. 833-845, 2019.

[52] R. Lal and P. A. Sanchez, Eds., Myths and Science of Soils of the Tropics, SSSA Special Publication, Madison, WI, USA, 1992.

[53] A. E. Hartemink, "Soil science in tropical and temperate regions-some differences and similarities," Advances in Agronomy, vol. 77, pp. 269-292, 2002.

[54] K. C. Tegha and Y. G. Sendze, "Soil organic carbon stocks in Mount Cameroon National Park under different land uses," Journal of Ecology and the Natural Environment, vol. 8, no. 3, pp. 20-30, 2016.

[55] B. Gèze, "Géographie physique et géologie du Cameroun Occidental," Éditions du Muséum, vol. 17, pp. 1-272, 1943.

[56] J. Gigou and C. M. Raunet, "Etude pédologique de la Plaine des Mbo (Ouest Cameroun)-Ministère de l'Agriculture, République Unie du Cameroun-IRAT, 1973-Ronéoté," 1973.

[57] R. Letouzey, "Etude phytogéographique du Cameroun. Edition Lechavalier, Paris Ve," 1968.

[58] IUSS Working Group WRB, World Reference Base for Soil Resources. International Soil Classification System for Naming Soils and Creating Legends for Soil Maps Update 2015. World Soil Resources Reports No. 106, FAO, Rome, Italy, 2015.

[59] Soil Survey Staff, Keys to Soil Taxonomy, USDA-Natural Resources Conservation Service, Washington DC, USA, 12th edition, 2014.

[60] FAO, Guidelines for Soil Description, FAO, Rome, Italy, 4th edition, 2006.

[61] G. K. Kome, R. K. Enang, B. P. K. Yerima, and M. G. R. Lontsi, "Models relating soil $\mathrm{pH}$ measurements in $\mathrm{H}_{2} \mathrm{O}, \mathrm{KCl}$ and $\mathrm{CaCl}_{2}$ for volcanic ash soils of Cameroon," Geoderma Regional, vol. 14, Article ID e00185, 2018.

[62] Soil Survey Staff, Soil Survey Laboratory Methods Manual. Soil Survey Investigations Report No. 42. Version 3.0, USDA, Washington, DC, USA, 1996.

[63] G. J. Bouyoucos, "Hydrometer method improved for making particle size analyses of soils 1," Agronomy Journal, vol. 54, no. 5, pp. 464-465, 1962.

[64] M. Pansu and J. Gautheyrou, Handbook of Soil Analysis: Mineralogical, Organic and Inorganic Methods, Springer Science and Business Media, Netherlands, 2007.

[65] C. D. Gross and R. B. Harrison, "Quantifying and comparing soil carbon stocks: underestimation with the core sampling method," Soil Science Society of America Journal, vol. 82, no. 4, pp. 949-959, 2018.

[66] G. K. Asamoa, "Particle size and free iron oxide distribution in some latosols and groundwater laterites of Ghana," Geoderma, vol. 10, no. 4, pp. 285-297, 1973.

[67] A. R. V. Wambeke, "Criteria for classifying tropical soils by age," Journal of Soil Science, vol. 13, no. 1, pp. 124-132, 1962.

[68] W. G. Sombroek and I. S. Zonneveld, Ancient dune fields and fluviatile deposits in the Rima-Sokoto River basin (NW Nigeria). Soil Survey Papers No. 5, Soil Survey Institute Wageningen, Netherland, 1971.

[69] C. L. Ping, G. J. Michaelson, C. A. Stiles, and G. González, "Soil characteristics, carbon stores, and nutrient distribution in eight forest types along an elevational gradient, eastern Puerto Rico," Ecological Bulletins, vol. 54, pp. 67-86, 2013.

[70] B. P. K. Yerima and E. Van Ranst, Major Soil Classification Systems Used in the Tropics: Soils of Cameroon, Trafford Publishing, Victoria, Canada, 2005.

[71] T. Takahashi and R. A. Dahlgren, "Nature, properties and function of aluminum-humus complexes in volcanic soils," Geoderma, vol. 263, pp. 110-121, 2016.

[72] B. T. Christensen, "Physical fractionation of soil and organic matter in primary particle size and density separates," Advances in Soil Science, vol. 20, pp. 1-90, 1992.

[73] W. Feng, M. Xu, M. Fan et al., "Testing for soil carbon saturation behavior in agricultural soils receiving long-term manure amendments," Canadian Journal of Soil Science, vol. 94, no. 3, pp. 281-294, 2014.

[74] E. M. Zelenak, "Relationship between munsell color value and organic carbon content in montana soils," MSc. dissertation, Montana State University-Bozeman, College of Agriculture, Bozeman, MT, USA, 1995.

[75] M. L. Pretorius, C. W. Van Huyssteen, and L. R. Brown, "Soil color indicates carbon and wetlands: developing a color-proxy for soil organic carbon and wetland boundaries on sandy coastal plains in South Africa," Environmental Monitoring and Assessment, vol. 189, no. 11, p. 556, 2017. 